\title{
The inward sublime: Kant's aesthetics and the Protestant tradition
}

Imagine great natural objects, scenes or events: waterfalls, the ocean churned up by stormy winds, or still and motionless, formations of clouds in the sky, thunder, deserts, a panther, preferably not behind bars but in its natural habitat. We may call all of this sublime, and if we do so, everybody will understand what we mean even if they do not agree. This general and colloquial use of our language refers to experience which for the first time was made a central subject of philosophical investigation in British 18th century aesthetic theory (cf. the classical overview of this tradition in Monk 1960). Joseph Addison and his successor, Edmund Burke, claim that we predicate natural objects or events as sublime if they have aroused the sensation of an 'agreable Horrour' in us (Addison 1965 [1711/12]). Whatever evokes the idea of pain and danger in an undirected lustful manner we call sublime (cf. Burke 1990 [1757], 36). The sublime experience (i.e. the experience of the 'sublime') is one of potential, but never of actual domination; personal safety is the prerequisite of our experiencing the sublime. Possible candidates have properties such as extensive size, overwhelming power, unpredictability, lack of contour or structure, infinity.

English philosophers give us a good description of what happens to us when we experience the 'sublime'. 'Horror' - and even more so 'terror'1 - may be a strong word for our feelings, but it certainly points in the right direction. There is something repelling about the sublime - being brought about, as Kant says, 'by the feeling of a momentary check to the vital forces' (Kant 1953 [1790], 91) and this effect has to do with the threat that we sense in the sublime. This threat appears to be latent, since no effective and identifiable power is actually used against us, and therefore our repellence contains, however faint and vague, eerie feelings. This is exactly what makes the sublime a source of 'horror'. Burke as well as Kant emphasize, though, that this repellence is only an integral part of an experience that contains attraction as well: the horror - in Addison's original words - is 'agreeable'. Burke even gives etymological references to support his argument that the differentiation between horror and delight, repellence and attraction is a merely analytical one. The Greek term 'thambos' means 'fear' or 'wonder', 'deinos' is 'terrible' or 'respectable' (Burke 1990 [1757], 54). Colloquial

1 'Indeed terror is always, either more openly or latently, the ruling principle of the sublime' (Burke 1990 [1757], 54). 
language proves, says Burke, that there are seemingly diametrically opposed feelings which are intrinsically connected, and the 'sublime' stands for (the source of) such ambivalent feelings. But neither Addison nor Burke has a satisfying answer to the question, though, as to why something that is identified as the source of a potential threat creates some sort of delight in us. ${ }^{2}$ The relief we feel when we realize that we are not affected by a potential threat caused by extensive size, overwhelming power, unpredictability, lack of structure or infinity is not synonymous with the feelings the 'sublime' arouses in us. Kant clearly saw this predicament inherent in English theory (cf. Kant 1953 [1790], 110). I am not going out on a limb when I say that Kant's 'Analytic of the Sublime' in his Kritik der Urteilskraft is the most influential philosophical approach to the phenomena in question. But although Kant's phenomenal analysis bears much similarity to Burke's, the core of the interpretation is diametrically opposed to that of Burke.

The sublime, according to Kant, is based on two different classes of phenomena. On the one hand, great natural objects, scenes or events, if they are of extraordinary dimension, transcend 'every standard of sense' (Kant 1953 [1790], § 25, 98). Therefore the imagination is incapable of comprehending what it has apprehended and representing it as a coherent form or a qualitative whole (cf. ibid., § 26, 99). The feeling of the sublime marks precisely the transition from the limits of understanding to the incomprehensible. It is aroused when our imagination evokes the idea of theoretical (i.e. mathematical) infinity in us but cannot sufficiently represent it - to sum up Kant's approach to the 'mathematically sublime'. On the other hand, great natural objects, scenes or events may obviously transcend our power to resist them and therefore be a potential threat to us (cf. ibid., 110). 'But, provided our own position is secure, their aspect is all the more attractive for its fearfulness; and we readily call these objects sublime, because they raise the forces of the soul above the height of vulgar commonplace [...]' (ibid., 110-1) - to sum up Kant's approach to the 'dynamically sublime'. Since these two concepts of the sublime are not mutually exclusive, something can be both mathematically and dynamically sublime, and often enough we would say that something is experienced as dynamically sublime because of properties which are the necessary and sufficient conditions of the mathematically sublime. In any case, the mathematically sublime and the dynamically sublime coincide in their contra-finality for their comprehension by us as rational beings. In Schiller's words, the mathematically sublime rejects our Fassungskraft ('power of comprehension') and the dynamically sublime our Lebenskraft ('power of life') (Schiller 1992 [1801], 610).

2 Burke offers some speculative explanations in reference to contemporary corpuscle theory, which to us do not sound convincing anymore. Cf. Burke 1990 [1757], 122-3. 
Kant concedes that nature causes the experience of the sublime in us. Here he is still in agreement with Burke. But in contrast to the Englishman, he rejects the idea that nature is also the object of the sublime. Once for all he states that 'the broad ocean agitated by storms cannot be called sublime' (Kant 1953 [1790], 92) - but Burke would have claimed precisely this. For Kant the ocean is 'horrible'. Burke would have agreed. But while he would have taken exactly this property as substantial to the ocean's sublimity, for Kant the churned up waters are just horrible - and nothing else. Obviously Kant plays on Addison's words: The agreeability of the horrible (which creates horror in us) has a source that does not lie in nature (ibid.). According to Kant, in our supposed confrontation with the sublime in nature, we experience the contra-finality of nature as illustrating our ideas such as infinity, eternity, freedom and might which we nevertheless can think very well (cf. ibid., 103) and - as far as they have (or should have) an impact on our practical life - feel committed to (ibid., 116). Nature evokes these ideas in us, but in such a way that at the same time we are conscious of its inability to demonstrate the intelligible. Hence the experience of the sublime is the experience of the individual as belonging to the community of rational beings. It is an experience that makes us aware of the idea of humanity in us and of our infinite superiority to the non-intelligible, i.e. to physical nature. It is only by a 'certain subreption (substitution of a respect for the Object in place of one for the idea of humanity in our own self - the Subject)' (ibid., 106) that we attribute to nature what actually is respect for our own vocation as rational beings. While our theoretical faculty of reason is mathematically sublime, our practical faculty of reason is dynamically sublime: Threatening natural objects or events might destroy our individual physical nature, but they could never even touch the rational vocation that defines our self-identity. In short: Organisms can be killed, not persons.

There are conceptual reasons for denying that Kant's theory of the sublime turned out the way it did because of his primary intention either to give a coherent interpretation of a phenomenon within his project of criticism and therefore to fulfill the standards of systemic coherence or to solve the immanent problems and imperfections of his predecessor's theories. First: Even if the author of the Kritik der Urteilskraft was forced to interpret the sublime according to the epistemological standards set by the author of the Kritik der reinen Vernunft, the final criterion for the validity of his theory is not systemic coherence but the appropriateness of the phenomenon's representation. Appropriateness again is defined by the probability of intersubjective rational consent. Therefore, explaining Kant's new way of thinking about the sublime by referring to the pressure of systemic coherence would provoke the question as to the origin of an increasing probability of intersubjective rational consent to Kant's theory of the sublime. Second: The claim that Kant represents the creative continuation of a particular tradition of aesthetic thinking 
(Burke) by means of its immanent criticism does not explain why Kant adopted this particular tradition and not a different one. Basic philosophical intuitions may be articulated in certain vocabularies handed down by tradition, and they may be specified by the inferential pressure inherent in any philosophical vocabulary chosen or developed, but they arise somewhere else. I propose that they are rooted in fundamental empractical patterns of understanding, which have been incorporated by individual thinkers during their socialization. ${ }^{3}$ The very idea of empractical patterns of understanding serves a heuristic function in my argumentation. It facilitates the hypothesis that Kant's 'Analytic of the Sublime' is founded in a collective attitude of mind as well as the correlating disposition to inner-directed experience and action which originates from the dominant version of Protestant piety in 18th century Germany. These originally religiously-generated attitudes and dispositions are weak determinant factors, in so far as they increase the chance that within a distinct frame of cultural space and time, which is dominated by Protestant inwardness, a way of thinking as it is displayed in Kant's idea of the sublime may emerge. From now on, I will call this way of thinking - in Kant's words, this 'Denkungsart' simply and briefly, the worldview of 18th century German Protestant piety.

In the following I will present the integral function of aesthetic experience within Protestant piety according to its religious ethics (I) and thereby focus on Johann Arndt's Wahres Christentum, the best known and most acknowledged edification book among Protestant believers in the early 18th century. It presents a 'programme' for leading the Protestant believer to 'true' Christian life. Then I will illustrate the aforesaid function of aesthetic experience within the worldview of Protestant piety by a close reading of three prominent German poems, which reflect and poetically codify the Protestant-Pietist experience of nature. ${ }^{4}$ After a close reading of Paul Gerhardt's Geh aus, mein Herz (II), Gerhard Tersteegen's Gott ist gegenwärtig (III) and Barthold Hinrich Brockes' Kirschblüte bei der Nacht (IV) the results of the interpretations are discussed with reference to the concept of the sublime (V), which will lead me back to Kant. I read his concept of the sublime as a philosophical transformation of what I will call the Protestant-Pietist worldview (VI).

3 I call empractical patterns of understanding convictions about what the case is and what should be the case within the meaning-laden world. These convictions take the form of practical attitudes and dispositions, be they attitudes of mind and experience or dispositions of action, and are displayed in thought, experience and action. They are so fundamental that the individual may not even be conscious that she expresses them in her particular way of thinking, experiencing and acting. And they develop in processes of longue durée, which are capable of adopting the most heterogeneous contents.

4 For the complete original text of these poems see the appendix. 


\section{At the spring of Protestant piety: Johann Arndt and the 'silent Sabbath' of inwardness}

Johann Arndt's Vier Bücher vom Wahren Christentum (1605-1609) was not just any publication among the diversity of edification books that flooded the book market of early 17th century Germany. It was more widely spread than any of Luther's books at the time. Arndt's Wahres Christentum and his Paradiesgärtlein voller Christlichen Tugenden (1612) 'may be looked at as the most influential devotional books in German Protestantism' (Schmidt 1979, 127; my translation M.S.). Johann Arndt counts as the direct predecessor or even founder of Pietism (cf. Stoeffler ${ }^{2}$ 1971, 202; Wallmann ${ }^{2} 1986 a, 14$ (incl. fn 51); 1990, 15; Brecht 1979, 148ff., 153-4; 1993, 131; cf. Sommer 1988, 135-42 on the history of research about Arndt), whose protagonists not only read his books intensively but also translated and published them, prayed and taught out of them. ${ }^{5}$ 'In the late 1600 s and early 1700s Arndt's Wahres Christentum was a common feature in almost every Lutheran family's private library in Northern Germany' (Wallmann 1986b, 176; my translation - M.S.), which is not even astonishing if one considers that between 1605 and 1740 this book was published in 123 editions (cf. Lehmann 1980, 114-5). 'Those who deal with Arndt', writes Johannes Wallmann to illustrate the importance of this author for German cultural history, 'do not ascend a lonely peak in the history of piety, but find themselves at the spring of a river that for centuries has traversed, irrigated and fertilized the land of Protestant piety' (Wallmann 1995, 5; my translation - M.S.).

In his Vier Bücher vom wahren Christentum, Arndt came to terms with his experience with the average piety of the Protestant population during the times when the denominations developed and differentiated. ${ }^{6}$ His book intends to

5 Philipp Jakob Spener and August Hermann Francke published Wahres Christentum; Nikolaus Ludwig Graf Zinzendorf translated it into French; Spener published his Pia Desideria at first as a preface to Arndt's Evangelienpostille, before it was published separately and advanced to being one of the most influential theological texts of Protestantism itself. Spener also held the so called Predigten über des seligen Johann Arndts Geistreiche Bücher vom wahren Christentum (prayers on Arndt's Wahres Christentum) and published them in 1711 in Frankfurt, Germany. August Hermann Francke strongly recommends, in his Idea Studiosi theologiae, that Arndt's Wahres Christentum become the most personal reference to every student of theology and be maintained through his whole life (Francke 1969 [1721], 174).

6 Cf. Schilling 1988. On the pastoral motivation of Arndt's literary production cf. Mager 1992. Wallmann interprets Arndt as a frustrated parish priest whose long years of tiring and resignating pastoral work brought about his desire to search for the spiritual springs of belief in the Protestant (as well as Catholic) literary tradition (Wallmann 1995, 9). 
overcome the denominational bounds in the name of a vital praxis pietatis that would unify all Christian believers. ${ }^{7}$ He wants to reach his goal with the idea of an imitatio Christi, which he interprets as the personal imitation of Jesus' life through ascetic self-discipline, the consequent rejection of worldly interests and a rigid exercise of Christian virtues. According to Arndt, we are obliged to lifelong repentance and this attitude should take the form of active contrition. Arndt is confident that true Christians may free themselves from the burden of sin caused by the transgression of Adam and Eve by resolute determination to virtuosic acts of repentance, while trusting the help of Christ as a 'doctor and spring'. ${ }^{8}$ The acts of repentance count on the help of Christ in a way that is analogous to the sick, whose care for their precarious health contains the regular use of their medicine. Consequent abstinence from all worldly affairs is the key orientation for the sinner's intended radical change. The turn to God progresses as a renunciation of the world by means of contemplation and reflexion. ${ }^{9}$ For Arndt, the love of God is primarily neither a practical attitude, nor the attention to the canonical religious texts (i.e. the bible). Instead, it is the realm of feeling where the believer 'meets' her God in loving togetherness.

Since there is nothing more beloved for the loving soul than Jesus, and no good higher and sweeter than God', our life would be 'the finest and most perfect if it returned to its origin, which is in God. But this can only happen if man goes within himself with all his might and renounces his knowledge, desire and memory of the world and all carnal affairs and turns his soul with all his desires to God through the Holy Spirit, rests and celebrates in distance from the world in a silent Sabbath; then God will begin to act on him

(Arndt 1845 [1605/09], 219, 325; my translation - M.S.)

Arndt presupposes that our soul is virtually different from the sinful world and that God, to whom man shall turn through contemplation, is 'inside' us and can be 'found' there.

7 Cf. Weber 1969. The purity of dogma has to be preserved, Arndt says, but the observance of a sacred life needs a much greater dedication: 'Die Reinigkeit der Lehre ist mit wachenden Augen zu bewahren; aber die Heiligkeit des Lebens ist mit größerem Ernst fortzupflanzen’ (Arndt 1845 [1605/09], 310). Even Hans Schneider, who stresses Arndt's antipathy for the Calvinists, concedes that his edification book rejects the common theologica polemica of his times and adapts preand non-Lutheran traditions (Schneider 1992, 297).

8 ‘Arzt und Heilbrunnen' (Arndt 1845 [1605/09], 136).

9 Arndt formulates this by combining the term 'Kehre' (a sharp turn or bend) with different prefaces ('hin', 'ab', 'ein', corresponding to the English prepositions 'to', 'off' and 'into'), which shall express that the practical orientations of turning to God, renouncing the world and contemplating the Christian truth 'in my heart' have the same root: Hinkehr through Abkehr by Einkehr myself. 
With reference to a prominent passage in the Gospel of Luke, Arndt explains precisely what we should understand by man's affectionate contemplation of his loving togetherness with Christ. The intention of his edification book was to show, 'how you may search and find the Kingdom of God in yourself' (ibid., 319). Arndt understands the Kingdom of God in a rather spiritualistic sense. He locates it in particular mental states of the contemplating believer with a variety of sensuous and emotional qualities that are identified by the use of an appropriate vocabulary. The verbalization of the believer's 'togetherness' with his God serves as reflexive insurance, because - as Kant put it with his deistic skepticism - how does one know 'that it was God speaking to him' in his emotional tete-à-tete (cf. Kant 1998 [1798], 333). Arndt uses an imagery of sensuous affection to conjure up the inner experience of salvation that is supposedly spontaneous and culminates in mystical states. Again and again he suggests the sensuous qualities of salvation by analogy to aesthetic experience: The Holy Spirit pours itself into the believer's soul and puts it into a state similar to our experience of the sun shining from within, the day shining from within, the fountain flowing from within and the rain flowing from itself and dampening everything (cf. Arndt 1845 [1605/09], 320). This repeated analogy intends to express the 'quasi-sensible' state of religious experience that William James pointed to ${ }^{10}$ and founded in 'mystical states of consciousness' ${ }^{11}$ The intended 'peak' of mystical experience is reached by creating a 'peaceful silence' (Stille) brought about by the radical abstinence from all worldly affairs. It is conveyed by a 'darkness' (Finsternis) of the mind, which we have to understand as surrendering its work of processing outer data and delivering representations of the empirical world to us. The meditative contraction of our consciousness to a point of utter concentration culminates in a moment which Arndt predicates as the rise of the 'godly light'. His imagery of light illustrates the 'togetherness' with God as a form of permeation and illumination characterized by a synthesis of recognition and union (unio mystica). It may hardly be verbalized, though, because whatever happens in this ominous moment, 'neither mind nor will nor memory may grasp or keep' (Arndt 1845 [1605/09], 333; my translation - M.S.). Because of the immediateness of its experience it is not sufficiently accessible in retrospect and therefore cannot be appropriately represented. It is

10 In his Varieties of Religious Experience, James argues (and also plausibly shows by interpreting conversion reports) 'that in the distinctively religious sphere of experience, many persons [...] possess the objects of their belief, not in the form of mere conceptions which their intellect accepts as true, but rather in the form of quasi-sensible realities directly apprehended' (James 1987 [1902], 64).

11 'I think that personal religious experience has its root and centre in mystical states of consciousness [...]' (ibid., 342). 
'hidden in the most inward depths and substance of the soul' (ibid.; my translation - M.S.). On the other hand, this incommensurability of the mystical experience may preserve its impact on everyday life, because what cannot be said appropriately maintains a never- dwindling source of interpretation and may be remembered as such: a mystical possession of the soul that has 'the Kingdom of God and its happiness in itself' (ibid., 331; my translation - M.S.).

Repentance, succession and regeneration are the central thoughts that are developed in the first three books of Arndt's Wahres Christentum. Now these three books are followed by a fourth one, which combines the edificatory intentions with metaphysical contemplation. For Arndt, the manifold forms in nature are formulations of the liber naturae, in which the true believer, who has undergone the process of repentance, succession of Christ and final regeneration, may read the creator's profession of loving us. Arndt intends to create the attitude of 'tasting' God's love and feeling ourselves within it by evoking a sentimental emotion at the sight of natural beauty - thereby returning God's love by means of an intentional stance toward nature. Our joy in nature and its usefulness for us have the status of a service. It makes us conscious of nature as a creation whose epitome we ourselves prove to be: the crown of creation as creation's internal selfconsciousness - being created by God to feel the joy at all the things we have at our (aesthetic and practical) disposal. ${ }^{12}$ The consciousness of nature's beauty as creation is a speculum of our soul's own beauty and proves our resurrection as the image of God, ${ }^{13}$ which is why actually God celebrates himself as the creator of all things by means of our - in Kant's words - aesthetic reflection. The true believer's aesthetic reflection on natural beauty is a form of godly self-celebration. ${ }^{14}$

I said that Arndt intends to return God's love by means of an intentional stance toward emotionally, sentimentally perceived nature. Of course, this is not the only way to return God's love, and it is not the primary one. As the design of his edification book clearly shows, the metaphysical contemplation of nature's beauty shall follow the believer's repentance, his succession of Christ and his regeneration, which again is founded in generally inner-directed and particularly mystical

12 Arndt 1845 [1605/09], 417 (der Mensch, 'von Gott geschaffen, daß er sich dessen freue, was er hat').

13 Sommer 1999, 216: 'Our amazement at the greatness of creation in all of its parts and of the care of God in it reaches a climax in the creation of man [...] The praise of God in his creatures and the beauty of the human soul, when God reflects himself in it - with this essential feature Arndt has returned to the beginning of the whole book' (my translation - M.S.).

14 The fact that Arndt's cosmology is based on the belief that God's love had been objectified in nature may also have been motivated by giving a consoling answer to the apocalyptical cosmologies of the baroque, which read natural objects and events as signs of the end of all times. Cf. Kemper 1987, 34-65. 
states of consciousness. The soul is the original 'location' where God is found, not nature. And the perception of nature's beauty derives from the experience of a beauty that is of a different kind: internal, non-sensuous, but 'quasi-sensible' (W. James), discovered in the most private mental states of the supposed 'togetherness' with God. Therefore it is Arndt's inner-directed piety that 'charges' the contemplation of nature sentimentally and turns the natural sphere into a reservoir of sentimental allegories, which not only appear in the 4th book, but generally and often in Wahres Christentum. The sentimental disposition of the believer toward nature is not the result of an immediate experience of nature, but its prerequisite. The subject becomes sentimental in his mystical experiences of permeation by and union with the godly might, and these experiences mediate the experience of nature, which is posterior to the latter.

Arndt's edification book intends to establish an aesthetically sensible, sentimental attitude toward nature as part of an overall concept of true piety. The goal of this piety is to guarantee salvation by means of quasi-sensible experiences through contemplation. For the believer, the object of this experience is God in myself'. I would thus like to call the basis of the true believer's certainty that she is on the right path a relation to God expressed as an emotional inner-directed self-relation. ${ }^{15}$ The object in itself of this relation is also relational (the self), but neither in terms of a reflexive nor in terms of an egological relation. We have to conceptualize it as a pre-intentional co-consciousness in any state of mind that this particular state of mind belongs to $m e .{ }^{16}$ The self-relation (in terms of a relation to the non-egological and non-reflexive self) is inner-directed, when the mental states have been evoked by inner stimulation (by bodily sensations or thoughts). Inner-directed self-relation therefore means the relation to inner-directed mental states (states evoked by inner stimulation) that I am pre-intentionally and co-consciously aware of as my mental states. The self-relation is emotional in as far as it is an emotional relation to the inner-directed mental states in question. Of course it is cognitive, too, because I must be capable of identifying discrete states of mind, but more importantly these states of mind are subject to an emotional

15 In the following I will operate with the distinction of 'inner-directed' and 'other-directed' self-relations. These terms will be exclusively used in the way I define them. They do not bear any similarity of meaning to David Riesman's differentiation of 'inner-directed' and 'other-directed' characters in Riesman 1989.

16 The philosophical discovery of this non-intentional co-consciousness is one of the great achievements of late 18th century philosophy. Rousseau calls it sentiment de l'existence; Novalis, Selbstgefühl. Cf. Manfred Frank's brilliant reconstruction of the historical genesis of Novalis' Selbstgefühl in German 18th century epistemology (Frank 2002). Also cf. Schlette 2005b (particularly in reference to contemporary conceptualizations of this self-relation in the Philosophy of Mind). 
relation; the self-relation's weight in the logic of belief derives from its emotional character. The second-order relation (i.e. the believer's relation to the relation he is as a self) is basically an emotion-bound interpretation of the first-order relation; it establishes what the object itself of the religious experience in question is for the believer. For him the first-order relation is a relation in which he not only relates to himself, but also to God ('in himself'). The believer interprets his first-order relation as a pre-intentional awareness of God. This interpretation is what takes place in a second-order relation to the (in itself relational) self, and it is emotion-bound, because for Arndt no cognitive relation may prove the authenticity of the supposedly identified mental state, but only the spontaneous emotional reaction to it. ${ }^{17}$

The attitude toward nature derives from the emotional inner-directed selfrelation. I would like to call it an emotional other-directed self-relation. The first-order relation of the self in this case comprises the pre-intentionality and coconsciousness of myself in those mental states that have been evoked by outer stimulation (namely natural objects, scenes or events). Again, the second-order relation is basically an emotion-bound interpretation of the first-order relation. Also in this case the first-order relation is a relation for the believer in which he relates to God 'in himself'. Again he interprets his first-order relation as a pre-intentional and co-conscious awareness of God. But whereas in the inner-directed self-relation, the mental states that prove God's presence to the believer are founded in the 'depths of his soul', i.e. in situations of inner stimulation, in the case of other-directed selfrelation the mental states that prove God's presence to the believer are founded in situations of outer stimulation (by nature). In short: Whenever I see (or have just recently seen) the beautiful natural, I feel God 'in myself'. Aside from the mere cosmological argument that nature is God's creation and God therefore - in the widest panentheistic sense - appears in nature, there is an experiential argument that God is present in nature. Because if I feel God in me whenever I approach the beauties of nature aesthetically, this presence of God 'in myself' must have been caused by something godly outside of me. But still I would not even sense it if I had not been previously assured of the existence of God in the mystical states of consciousness.

17 Actually the logic of pietist belief according to Arndt is far more complicated, because the spontaneous emotional reaction has to be made subject to an even higher-order observance. 'Examine the depths of your heart, how it is there', Arndt requires of the true believer (Arndt 1845 [1605/09], 148; my translation - M.S.); cf. other characteristic examples of the demanded observance in the records of Philipp Jakob Spener's pietist collegia: Spener 1979 [1687], 479 [and repeatedly]). This may initiate a regressus ad infinitum that leads into the struggle of penance (Bußkampf) which characterizes the most dominant form of pietism in the18th century, the Hallensian pietism, established by August Hermann Francke. Cf. my reconstruction of the pietist logic of belief in Schlette 2005a. 
It will be interesting to see how this 'logic' of piety - particularly the proportion between the inner-directed and the other-directed self-relations which Arndt introduces to us theologically - is expressed in a worldview, i.e. in empractical patterns of understanding. When I assign the texts I interpret to the Arndtian tradition of Protestant piety, then I mean this in terms of a praxis pietatis that has been most effectively explicated as well as initiated - although certainly not exclusively initiated - by Arndt's edification literature. I do not mean this in terms of direct causation. Although all of the authors I deal with were shaped by a religious milieu that was inspired by Arndt, it would not make sense to say that reading Arndt caused these authors to write and think the way they did. Growing up in this milieu greatly increased the chance that the way these authors thought, experienced and acted took the form it did. Let us now - using Pierre Bourdieu's distinction (cf. Bourdieu 1974, Chap. IV) - focus on an opus operatum that paradigmatically expresses the modus operandi of the piety in question.

\section{2 'Go forth my heart and pleasure seek': Paul Gerhardt and the Protestant piety of nature}

The opus operatum of inner-directed Protestant piety that I will discuss first is the church song Geh' aus, mein Herz, und suche Freud ${ }^{18}$ by Paul Gerhardt. ${ }^{19}$ Again this is not just one text among many, but the most well-known example of Protestant piety of nature. ${ }^{20}$ Understanding this poem brings us to the heart of 18 th century Protestant Germany. And it is no coincidence, as I will show, that Gerhardt's

18 'Go forth/out my heart and pleasure seek', as the title is usually translated in English editions. 19 Paul Gerhardt was born in 1607 in Gräfenhainichen (Palatine Saxony) and went to the royal school (Fürstenschule) in Grimma, before he began to study theology in Wittenberg in 1628. Between 1643 and 1651 he worked as a tutor in Berlin where he later worked as a deacon at St. Nicolai. Not willing to renounce his orthodox-Lutheran polemics against other confessions during church services, as he was required to do by the ruling prince, he was relieved of office in 1666. In 1669 he became deacon in Lübben (Niederlausitz), where he died in 1676. The most productive phase of his poetry was during his time as a tutor in Berlin. Between 1647 and 1736 his church songs were published in more than 40 editions of the Protestant hymnbook Praxis pietatis melica. Johann Georg Ebeling published the first complete edition of his songs in 1667 under the title Pauli Gerhardi Geistliche Andachten. Generally on Gerhardt cf. Bunners 1993; on the poetological assessment of Gerhardt cf. Hillenbrand 1992; particularly on Gerhardt's song Geh aus, mein Herz, und suche Freud cf. ibid., 101-106; Schmidt 1982, 285-302.

20 On the relation between church songs and Protestant piety in 17th century Germany cf. Brecht 1993, 188-203; on the religious poetry of nature in Germany cf. Krummacher 1976; Kemper 1981. 
poem was added to 19th century editions of Arndt's Wahres Christentum. A close reading of it shall prepare the appropriate attitude toward the subject of the fourth (cosmological) book because Gerhardt's language evokes the very sentimentalism that correlates with Arndt's theology of piety psychologically. ${ }^{21}$

1) Geh' aus, mein Herz, und suche Freud' / In dieser lieben Sommerzeit / An deines Gottes Gaben; / Schau an der schönen Garten Zier, / Und siehe, wie sie mir und dir / sich ausgeschmücket haben.

2) Die Bäume stehen voller Laub, / Das Erdreich decket seinen Staub / Mit einem gruenen Kleide; / Narzissus und die Tulipan, / Die ziehen sich viel schöner an / Als Salomonis Seide.

3) Die Lerche schwingt sich in die Luft, / Das Täublein fleucht aus seiner Kluft / und macht sich in die Wälder; / Die hochbegabte Nachtigall / Ergötzt und füllt mit ihrem Schall / Berg, Hügel, Tal und Felder.

4) Die Glucke führt ihr Völklein aus, / Der Storch baut und bewohnt sein Haus, / Das Schwälblein speist ihr Jungen; / Der schnelle Hirsch, das leichte Reh / Ist froh und kommt von seiner Höh / Ins tiefe Gras gesprungen.

5) Die Bächlein rauschen in dem Sand / Und malen sich und ihren Rand / Mit schattenreichen Myrten; / Die Wiesen liegen hart dabei / Und klingen ganz von Lustgeschrei / Der Schaf und ihrer Hirten.

6) Die unverdroßne Bienenschar / Zeucht hin und her, / sucht hier und dar / Ihr edle Honigspeise; / Des süßen Weinstocks starker Saft / Kriegt täglich neue Stärk und Kraft / In seinem schwachen Reise.

7) Der Weizen wächset mit Gewalt, / Darüber jauchzet Jung und Alt / Und rühmt die große Güte / Des, der so überflüssig labt / Und mit so manchem Gut begabt / Das menschliche Gemüte.

8) Ich selbsten kann und mag nicht ruhn, / Des großen Gottes großes Tun / Erweckt mir alle Sinnen: / Ich singe mit, wenn Alles singt, / Und lasse, was dem Höchsten klingt, / Aus meinem Herzen rinnen.

9) Ach, denk ich, bist du hier so schön / Und läßt du's uns so lieblich gehn / Auf dieser armen Erden: / Was will doch wohl nach dieser Welt / Dort in dem reichen Himmelszelt / Und güldnem Schlosse werden!

10) Welch hohe Lust, welch heller Schein / Wird wohl in Christi Garten sein! / Wie muß es da wohl klingen, / Da so viel tausend Seraphim / Mit eingestimmtem Mund und Stimm / Ihr Alleluja singen!

21 On the mystical strains of Gerhardt's piety in his songs cf. Petrich 1914, 197ff.; van Andel 1976, 173-9. Gerhardt's piety of nature 'derives from Arndt's “LIBER NATURAE” and participates in the very old dogma about nature as the second book of God's revelation (next to the Liber Dei, the bible) that reaches back to Augustine and Origines' (Haufe 1978, 73; my translation - M.S.). 
11) O wär ich da, o stünd ich schon, / Ach, süßer Gott, für deinem Thron / Und trüge meine Palmen! / So wollt ich nach der Engel Weis / Erhöhen deines Namens Preis / Mit tausend schönen Psalmen.

12) Doch will ich gleichwohl, / Weil ich noch / Hier trage dieses Leibes Joch, / Auch nicht gar stille schweigen; Mein Herze soll sich fort und fort / An diesem und an allem Ort / $\mathrm{Zu}$ deinem Lobe neigen.

13) Hilf nur und segne meinen Geist / Mit Segen, der vom Himmel fleußt, / Daß ich dir stetig blühe; / Gib, daß der Sommer deiner Gnad / In meiner Seelen früh und spat / Viel Glaubensfrücht erziehe.

14) Mach in mir deinem Geiste Raum, / Daß ich dir werd ein guter Baum, / Und laß mich wohl bekleiben; / Verleihe, daß zu deinem Ruhm / Ich deines Gartens schöne Blum / Und Pflanze möge bleiben.

15) Erwähle mich zum Paradeis / Und laß mich bis zur letzten Reis / An Leib und Seele grünen: So will ich dir und deiner Ehr / Allein, und sonsten keinem mehr, / Hier und dort ewig dienen“ (Gerhardt 1992 [1667], 71).

Let us focus on the first stanza of Gerhardt's song. ${ }^{22}$ In our context, 'Geh aus!' has the performative meaning of an encouraging invitation to leisurely leave a closed space and enter an open one. The addressee of this invitation is metonymically referred to as the alter ego of the lyric self ('mein Herz'), ${ }^{23}$ and thereby the dichotomy of 'inside' and 'outside' is specified as the opposite between the inwardness of emotional life and the openness for sensuous impressions. ${ }^{24}$ As a form of the lyric self's invitation to itself, the beginning of the stanza expresses a relation, which contains the lyric self in two intentionally different ways: directly as the invitee and indirectly as the inviting instance. The poem takes off from an innerly self-relation, a way of addressing oneself to turn to the outside. Now, if one wants to seek pleasure in the outer world, it should be such that one may also find what one is looking for. The temporal reference 'in dieser lieben Sommerzeit' charac-

22 For a translation I suggest the following: Go forth, my heart, and seek pleasure in this beautiful summertime, enjoying the gifts of your God. Look, see the beauty of the delightful garden's decorations and see how they have decked themselves out for you and for me.

23 Another logically possible way of reading the formulation would be the assumption of another person that is referred to using a nickname. This version can be excluded considering the further context of the poem.

24 Bunners' suggestion that the invitation to go out expresses the 'turn to God' is semantically unfounded and caused by the projection of the end of the poem into its beginning (cf. Bunners 1993, 198). Lothar Schmidt also refers to the form of address, without having much to say. It was a common topos that could be shown in German lyricism from Friedrich von Hausen to Christine Busta, as he remarks (L. Schmidt 1982, 285). His claim this is a mere formula ignores the necessary interpretation and thereby fails to identify the logic of contentual development in this poem. 
terizes the outer world as the most pleasurable natural season (certainly for most people in the 17th century). The suggested emotional dedication of the heart to a sphere external to the heart is corresponded to by reference to a natural season that is compatible with the sentiments of the heart. ${ }^{25}$

So far the stanza lacks an explicit reference to God: It merely encourages the sentimental admiration of nature. But this is followed by a subtle indication (the last one until the 7th stanza) that Gerhardt wrote the church song with the intention of praising God: the pleasure may be sought for '[A]n deines Gottes Gaben'. The flourishing nature that has been evoked by reference to the natural season of summer is predicated as a gift of God, and this God is being called the God of the heart ('among the gifts of your [the heart's - M.S.] God'), which characterizes the joy felt at the sight of nature as a sentimental form of worship. Above all, if God is the God of the heart, then the relation to God is characterized by their 'togetherness', whose utmost possible privacy is reached through mystical states of consciousness. ${ }^{26}$ The relation to nature and to God through his 'perception' in nature are subordinated to the latter. The gifts of God 'speak' to the heart that originally senses him inwardly and only secondarily becomes aware of him by outer stimulation.

The fourth line of the first stanza is the paratactical continuation of the preceding three lines, and it specifies the encouragement to 'go forth' as an invitation to look at the ornamental decorations of the natural beauties. The sentimental self (i.e. 'the heart') shall seek the pleasure of aesthetically contemplating nature. It is not encouraged to practically engage in its shaping, arrangement and practical exploitation. The scenery that is being evoked alludes to the peaceful idyll of the Garden of Eden, in which we see God walking among his creation with the pride of a successful craftsman (cf. Gen 3, 14). The aesthetic contemplation determines what the lyric self is specifically focusing on in nature. It is its decorativeness - in Kant's words: its aesthetic finality - that appeals to the contemplator. The fifth line says that the natural beauties have decorated themselves 'for me

25 This becomes obvious if you substitute the attribute 'kalt' (cold) for 'lieb' (lovely), which would ridicule the invitation, whereas a 'stormy' or 'hot' summertime would allude to the emotional opening as an erotically compulsive one.

26 This becomes more obvious, indeed, if you consider Gerhardt's poetic production as a whole. Lines like 'Was ist's, o Schönster, das ich nicht / In deiner Liebe habe' are formulated in the spirit of mystical contemplation that seeks visualization of the passion of Christ and unification with Jesus. Gerhardt was greatly inspired by St. Bernhard, whom he explicitly refers to as a primary source of his poetic imagination (cf. his Passionssalve des heiligen Bernhardi an die Gliedmaßen des HErrn JEsu, containing Gerhardt's maybe most famous church song 'O Haupt voll Blut und Wunden', a masterpiece of poetry that belongs to the pantheon of German literature for its authentic articulation of German Protestant inwardness). 
and you', suggesting that nature's aesthetic finality may unify reason and heart. This arrangement does not reveal an order, though, which has been established in nature by a gardener (whether it be man or God), because the gardens have decorated themselves ('Und siehe, wie sie [...] / Sich ausgeschmücket haben'): It reveals an order nature has established itself. God may be present in all the astonishing natural objects, but above all he is present in the 'heartbeat' of an organism that may unfold itself to the diversities of natural forms according to the immanent logic of its (the organism's) development. ${ }^{27}$

Gerhardt evokes a harmonic correlation between aesthetic and teleological finality. And within Gerhardt's religious worldview, as it is being expressed in his church song, the explicit consciousness of nature's teleological finality follows the aesthetic awareness of its beauty. Accordingly, stanzas two to five refer to the beauty of nature, ${ }^{28}$ before stanzas six and seven accentuate nature as a teleological ensemble. ${ }^{29}$ It is not until the seventh stanza that God as the originator

27 The second half of the second stanza confirms this interpretation: 'Narzissus und die Tulipan, / Die ziehen sich viel schöner an / Als Salomonis Seide' (the daffodils and tulips are dressed finer than in Salomo's silk). These lines metonymically allude to Salomo's enormous wealth. But silk is also a symbol of the orient's aesthetic sophistication. Gerhardt indirectly approves of this because the comparison says that the delicate fabric that we associate with the name of Salomo is surpassed by the flowers, whose splendour adorns the gardens. Gerhardt may also have been inspired by Mt 6, 29, where Jesus tells his successors to learn from the lilies, which grow on the fields: they were not working, nor spinning, but even Salomo, in all of his splendour, had not been dressed as beautifully as any one of them. The passage in the bible is intended as an allegory of God's care, though. The same way in which God knows how to dress the useless flowers, he also knows to give man all he needs. This meaning is not preserved in Gerhardt's implicit allusion to the biblical text because for Gerhardt the beauty of nature derives from its own impulse to beautification. It is this impulse that is primarily of godly origin.

28 Nature's beauty is referred to as the movements and melodious sounds of the birds ('Die Lerche schwingt sich [...]' [the lark is swinging itself into the air]; 'die [...] Nachtigall ergoetzt und füllt mit ihrem Schall'[the nightingale enthralls and fills with its song]); the characteristic properties of the wild animals common to the habitat of Central Europe ('der schnelle Hirsch, das leichte Reh'[the fast stag, the light deer]); the sound and the quasi-artificial course of the creeks ('Die Bächlein rauschen [...] und kränzen sich [...]' [the creek is rustling ...]); the pleasant order of the natural scenery as a whole ('die Wiesen tränken sich dabei'[the meadows lie next to it]). Being aware of the acoustic and visual stimuli merging to a qualitative unit, the heart may seek its pleasure. - L. Schmidt has mentioned the affinity of Gerhardt's song to the literary tradition of the locus amoenus (Schmidt 1982, 288). Gerhardt brings anacreontic and biblical motives to a harmonic fusion.

29 The teleological finality is merely seen out of a physicoteleological perspective, of course, that interprets the natural design as an order serving the needs of man (whereas it is logically possible to conceptualize the teleological finality merely in functional terms). Gerhardt refers to the honey production of the bees, the flourishing of the vine, the growth of wheat. Hillenbrand 
of nature's finality is explicitly mentioned again. And here Gerhardt primarily points out the aesthetic qualities of nature again: Everybody, young and old, praises the great loving kindness of Him who 'so abundantly refreshes the human soul with a good many faculties' ('... so überflüssig labt / Und mit so manchem Gut begabt / Das menschliche Gemüte'). The essentially contemplative and aesthetic features of this song are confirmed even in those passages, which stress the utility of nature for man. These features are even more accentuated by the fact that the loving kindness of God is not only praised for the sake of nature, but also for the sake of the joy we may feel while contemplating nature's aesthetic and teleological finality. With no doubt 'a good many faculties' refers to our capability of feeling joy at the beauties of nature. The piety of nature expressed in the song culminates in the reflection that this pietist capacity of joy in nature itself came to be through God. From now on the lyric self expresses nothing but enthusiasm due to its insight into God's hidden effects on man. Therefore, the seventh stanza is the turning point of the poem: In what follows, the lyric self exclusively focuses on God, of whom it became aware through aesthetic contemplation.

It is not difficult to detect the relation to God by means of inner-directed and other-directed self-relations in the opus operatum (Bourdieu) of Gerhardt's song. The opening up to the world of summer can be decoded as an emotional other-directed self-relation, in which nature serves mainly as a confirmation of the qualitative content that is 'found' in the self's more fundamental innerdirected self-relation. This inner-directed self-relation is the experiential background of the poem and it is only indirectly evoked by the imperative phrase. ${ }^{30}$ More specifically, the poem articulates a religious experience whose development may be reconstructed as the elevation of the self: from an intuitive feeling of God which belongs to the inwardness of the (ideally) mystically aroused religious self (indirectly expressed by the implicit meaning of the imperative's address at the beginning of the first stanza); over the sensuously mediated experience of God through the aesthetic (stanzas 1-5) as well as teleological (stanzas 6-7) contemplation of nature; and the explicit recognition of God - through self-reflection as

deciphers these passages as hidden biblical references that intend to evoke the 'eschatological dimension of salvation' (Hillenbrand 1992, 101; cf. ibid., 103). Hillenbrand's interpretation is plausible, but it cannot disprove that the text primarily articulates a particular religious attitude toward nature. Thus it has maintained its attraction to Protestant believers and still is a prominent keystone of liturgy.

30 That is why the way from the inward to the outward relation to God by means of natural experience and back is not a hermeneutic circle, as Schmidt claims (1982, 290). The hermeneutic circle consists of preliminary judgments, their revision, transformation and reestablishment on a higher level, which for Gerhardt would be a blasphemously relativistic perspective on the revelation of truth in the inward states of mystical consciousness. 
a contemplator of nature (stanza 7) as well as the reflection of nature as corresponding to the attitude of contemplation (stanza 7 and 8); to the direct experience of God - through the contemplation of his transcendence (stanzas 9-11), which 'takes off' from empirical experience by ascribing an allegorical meaning to some of the objects and facts experienced. The eleventh stanza is the peak of this elevation. The four last stanzas serve the function of an epilogue: The lyric self declares his humble acceptance of human faith (stanza 12) and prays for support in the struggle for religious authenticity and salvation (stanzas 13-15).

Gerhardt's song paradigmatically expresses the Arndtian worldview. It will be interesting to see how this worldview, which is commonly associated with the notorious forms of sentimentalism in 18th century Germany, proves to be fundamental to sentimentalist as well as rationalist attitudes of mind and experience. In what follows, I will contrast Gerhard Tersteegen's church song Gott ist gegenwärtig, a paradigmatic poetic example of religious sentimentalism, with Barthold Hinrich Brocke's poem Kirschblüte bei der Nacht, which is no less paradigmatic for the rationalist worldview. Both authors have been shaped by the Arndtian tradition of Protestant piety.

\section{3 'let me [...] let you affect me': Gerhard Tersteegen and the sentimentalist transformation of the piety of nature}

Let us first take a look at Gerhard Tersteegen's complete poem, before we particularly focus on the sixth stanza ${ }^{31}$ :

31 Gerhard Tersteegen, born in Moers in 1697, grew up in a Reformed family and went to the local Latin school for over nine years. Financial considerations caused his family to push him to move to Mühlheim an der Ruhr and start an apprenticeship as a merchant there. Tersteegen made contact with quietist circles and, after having had a conversion experience, he resigned the job his family had chosen for him and worked as a weaver until 1728, when he gave up this work to dedicate himself exclusively to religiously edifying activities in the context of quietism. He translated Jean de Labadie and Thomas a Kempis, wrote a collection of songs under the title Geistliches Blumengärtlein inniger Seelen and between 1733 and 1753 a major biographical work called Auserlesene Lebensbeschreibungen heiliger Seelen. The sermons he held between 1769 and 1773 have been published under the title Geistliche Brosamen. Tersteegen died in 1769 in Mühlheim an der Ruhr. On the literary significance of Tersteegen cf. Kemper 1997, 58-95; on the impact of mysticism on Tersteegen's opus cf. van Andel 1973 and - for the opposite reading - Wolff 1989. Whereas van Andel characterizes Tersteegen as a quietist mystic, whose piety contradicts the principles of reformation, Wolff accentuates its compatibility with Lutheranism. Also cf. the 
1) "Gott ist gegenwärtig! Lasset uns anbeten, / Und in Ehrfurcht vor ihn treten. / Gott ist in der Mitte! Alles in uns schweige, / Und sich innigst vor ihm beuge. / Wer ihn kennt, Wer ihn nennt, / Schlag die Augen nieder, / Kommt, ergebt euch wieder.

2) Gott ist gegenwärtig, dem die Cherubinen / Tag und Nacht gebücket dienen; / Heilig! heilig! singen alle Engel-Chören, / Wenn sie dieses Wesen ehren; / Herr, vernimm Unsre Stimm, / Da auch wir Geringen / Unsre Opfer bringen.

3) Wir entsagen willig allein Eitelkeiten, / Aller Erdenlust und Freuden; / Da liegt unser Wille, Seele, Leib und Leben, / Dir zum Eigenthum ergeben: / Du allein Sollst es sein, / Unser Gott und Herre, / Dir gebührt die Ehre.

4) Majestätisch Wesen, möcht ich recht dich preisen, / Und im Geist dir Dienst erweisen ! / Möcht ich, wie die Engel, immer vor dir stehen, / Und dich gegenwärtig sehen! / Laß mich dir Für und für / Trachten zu gefallen, / Liebster Gott, in allen.

5) Luft, die alles füllet, drin wir immer schweben, / Aller Dinge Grund und Leben, / Meer, ohn Grund und Ende, Wunder aller Wunder, / Ich senk mich in dich hinunter: / Ich in dir, Du in mir, / Laß mich ganz verschwinden, / Dich nur sehn und finden.

6) Du durchdringest alles: laß dein schönstes Lichte, / Herr, berühren mein Gesichte: / Wie die zarten Blumen willig sich entfalten, / Und der Sonne stille halten, / Laß mich so, Still und froh, / Deine Strahlen fassen, / Und dich wirken lassen.

7) Mache mich einfältig, innig, abgeschieden, / Sanfte, und im stillen Frieden, / Mach mich reines Herzens, daß ich deine Klarheit / Schauen mag im Geist und Wahrheit. / Laß mein Herz Ueberwärts, / Wie ein Adler schweben, / Und in dir nur leben.

8) Herr, komm in mir wohnen, laß mein'n Geist auf Erden / Dir ein Heiligthum noch werden: / Komm, du nahes Wesen, dich in mir verkläre, / Daß ich dich stets lieb und ehre; / Wo ich geh, Siz und steh, / Laß mich dich erblicken, / Und vor dir mich bücken. (Tersteegen 1927 [1729], 235)

psychological analysis of Tersteegen's biographical development in Hoffmann 1982 and the publications on Tersteegen in Kock/ Thiesbonenkamp 1997. On the significance of Tersteegen's song Gott ist gegenwärtig for his overall piety cf. Ludewig 1986 (with a theological perspective on Tersteegen) and Kemper 1997, 58-95 (from the standpoint of literary studies). Tersteegen's songs are examined particularly in context of pietist song production in Althaus 1997. 
Now, rather than starting at the beginning of Tersteegen's song, I would like to begin with the sixth of eight stanzas. ${ }^{32}$ Gerhard Kaiser $(1996,33)$ has pointed out that it ideally exemplifies how, within the mindset of 18th century pietism - almost a hundred years after Gerhardt's song was written - the sentimental experience of nature becomes independent from its original religious origins. My main intention in the following is to question this popular thesis, which has become common textbook knowledge about pietist literature in German Studies. Kaiser writes that this stanza articulates the sensitivity to ('Einfühlung in [...]') a precisely observed natural event. The flowers are not only a metaphor for the human soul, but according to Kaiser $(1996,34)$ they are described as entities that have a soul themselves. And he explicitly contrasts Tersteegen's individualized way of writing about nature with the supposedly merely allegorical approach of Gerhardt in Geh aus, mein Herz, und suche Freud. And indeed, Kaiser is right about the higher degree of poetic individualization in Tersteegen's poem. Whereas Gerhardt's poem seems to be about experienced nature, Tersteegen's deals with actually experiencing it. Whereas Gerhardt gives us a panorama, Tersteegen gives us a situation (of experiencing). But let us focus on the stanza more closely. What does the lyrical self say about the flowers? It describes the flowers' sensitivity to sunshine as a conscious act; the flowers unfold willingly and remain still in the sun. This formulation logically implies that flowers take an intentional stance toward their own sensuous states (which are caused by sunshine). But what the lyrical self says is not identical with what the text means. It does not mean that the flowers intend a qualitative mental state, and it does not mean that they intend to unfold and to remain still in the sun. It does not even mean that they have any qualitative mental states at all. The text does not give us a biological hypothesis about natural life. Instead, these lines can only be understood metaphorically. Let me try to reconstruct the logic of aesthetic perception that is expressed in the stanza.

It begins with the proposition that God (to whom the personal pronoun refers) permeates everything. This proposition formulates a conviction that can be interpreted either as a claim or an expressive statement. Our stanza does not make this conviction plausible; it presupposes its plausibility. Either the lyric self has proven it in the foregoing stanzas or it does not do so at all. In any case, the sixth stanza only continues with what follows from this conviction. Now it is unlikely, of course, that God's actual permeation of everything is meant in a physical sense. Therefore, the very use of the verb 'permeate' is metaphorical. It

32 As a paraphrasing translation I suggest as follows: You permeate everything. Let your most beautiful light, my Lord, touch my face: How the gentle blossoms unfold willingly, and hold still in the sun: let me this way, quietly and gladly, grasp your rays and let you affect me. 
indicates the effect of God in the world (including his effect on man, of course) as a form of unification or fusion; it indicates a panentheistic worldview. This conviction makes the lyric self appeal to God with his request: 'Let your most beautiful light, oh Lord, touch my face' ('laß dein schönstes Lichte, / Herr, berühren mein Gesichte [...]'). And we are right to believe that the Godly acts of permeation are metaphorically illustrated by the word 'light', since that refers to the apparently least material matter we may most clearly perceive and therefore ideally serves the illustration of a spiritual permeation. God's might is visualized by its illustration as a light that he shall instruct to touch the face of the lyric self. But at this point Tersteegen manages a subtle fading of the noumenal into the phenomenal sphere. Strictly speaking, he would have to say that the light of God was told to permeate the soul or heart or even the mind of the lyric self (as the common mystical formulations go), but certainly not touch its face. The focus of the lyric self changes from the contemplation of God's might to empirical sensuous experience. We witness a metamorphosis of the metaphorical use of the term to its literal use, from the metaphysical entity that permeates everything to the physical light that touches everything, from God to sunshine. We almost feel enticed to appeal to the lyric self with Gerhardt's words: 'Go forth, my heart, and pleasure seek [...]!' But in contrast to Gerhardt's heart, the lyric self in Tersteegen's song does not need any invitation, although the context of our stanza gives us all rights to identify it with the same semantic sphere to which Gerhardt alludes by using the term 'heart' as a metonymical reference to the lyric self's emotional inwardness. Why is that so? Why does 'the heart' in Tersteegen's text not need any invitation to go forth and seek pleasure in the natural world? To answer this question we are forced now to consider the foregoing stanzas of Tersteegen's song.

The song begins, in the first (and again in the second) stanza, with the exclamation 'Gott ist gegenwärtig!' (God is present!), and thereby introduces itself as a form of expressive communication. The lyric self never explicitly tells us exactly in what God is present; instead it evokes the idea in us of what it is to feel this presence. At first this feeling still seems to be integrated into a liturgical context. ${ }^{33}$ But then the lyric self begins to worship in a way that fully abstracts from all possible aspects of communal experience. It reaches its destination in the fifth stanza, where the liturgical context has fully disappeared behind the emphatic expression of the self's atmospheric stimulation: 'Air that fills everything, in which we hover/ ground and life of all things that be, sea without bottom and end, wonder of all wonders ...'

33 Cf. the first stanza: 'Lasset uns anbeten [...] Gott ist in der Mitte' ('Let us pray to God [...] God is among us' [or: 'God is in the centre' - depending on the interpretation]). Cf. the songbook of the German Protestant church (EKG), where Tersteegen's song is printed in the chapter 'Service' under the category 'For the entry' ('Zum Eingang') (EKG, no. 128). 
(Luft, die alles füllet, drin wir immer schweben, / Aller Dinge Grund und Leben, / Meer, ohn Grund und Ende, Wunder aller Wunder,'). Hans-Georg Kemper does not fully grasp its character. He writes that 'in looking at nature the biblical-personal God [...] literally vanishes into the "air" and "ocean" - that is the elements' (Kemper 1993, 138; my translation - M.S.). In fact, the language does not - as Kemper claims evoke a view or look at nature, but a 'quasi-sensible' awareness of God that is more appropriately described as an overall bodily sensation of inner (not outer) stimuli. This sensation temporarily revokes the subject-object-dichotomy, which is always implied when we visually focus on something (like the air or the ocean). Therefore we cannot speak of a natural experience in the strict sense of the word here, since it is not an experience of something that may serve as a distinct intentional object of the experiencing subject. 'Air' and 'ocean' are metaphors that illustrate the nunc stans of a mystical experience. They seem appropriate because it is their properties - a seeming infinity (air and ocean), immateriality (air) and, last but not least, a tactile bodily stimulation (ocean) - which create the impression of a dissolution in the surrounding waters that corresponds to the particular mystical state articulated by the lyric self. Its inner stimuli result in a sensitivity to the suddenness (symbolized by the infinity of air and ocean), the spirituality (symbolized by the immateriality of the air) and the 'quasi-sensible' lustfulness (symbolized by the dissolution associated with the ocean) of the experience. Consequently the stanza ends with the lines: 'I sink into you: I in you, you in me, have me fully disappear, only you to see and find' ('Ich senk mich in dich hinunter: / Ich in dir, Du in mir, / Laß mich ganz verschwinden, / Dich nur sehn und finden').

These lines directly precede the sixth stanza which begins with the proposition 'You [i.e. God - M.S.] permeate everything'. We can see now that it is the articulation of subjective, 'quasi-sensible' evidence gained by mystical experience. And we can also see why this experience seems to intrinsically move the emotionally aroused self toward the perception of nature, whereas in Gerhardt the emotionally determined self (i.e. the heart) needed an explicit invitation. The inwardness indirectly alluded to in Gerhardt simply must be different from Tersteegen's inwardness. The latter is much more sensuously determined than Gerhardt's. It is therefore determined to a greater openness to nature. The overall sensitivity to atmospheric stimulation is apt to turn the self to the outer world. Let us see now how precisely this attitude is formulated in Tersteegen's text. As we said, the request for spiritual permeation in the first two lines of the sixth stanza fades the noumenal into the phenomenal. What goes on in the lyric self is actually similar to the state of day dreaming, where we may suddenly become aware of already long-perceived, but not yet consciously represented data from the outer world, just because the contents of our day dreams dispose us to consciously focus on the perceived data. Analogously, the lyric self's sensuous contemplation of a God that may permeate 
everything is disrupted by the sudden and immediate evidence of the sunshine which seems to touch everything in a gentle manner. The metaphysical contemplation has suddenly drawn the attention to a 'physical' fact and the perception of this fact superimposes the metaphysical contemplation. Therefore, the second line oscillates between the articulation of an inner and an outer sensation. More importantly, the perspective from which the outer sensations are consciously represented is determined by the previous inner sensation of God. Therefore, the proposition, which articulates the awareness of the 'physical' fact (namely 'The gentle flowers willingly unfold and remain still in the sun'), is adjusted to the grammatical frame of a comparison, whose function is the formulation of an allegory.

Let us return now to the two crucial lines about the flowers. What the lyric self says is not what is meant, as I claimed in contradiction to Gerhard Kaiser's interpretation. The lyric self suggests the sensitivity and intentionality of the perceived flowers. But considering the context, this means that a 'physical' fact is seen in the light of the self's own mystical inspiration. It projects features into the flowers that are actually features of the self's mystically generated disposition to a given experience at a given moment. After God has revealed himself to the self with inward, yet 'quasi-sensible' evidence, the self is prepared to see the world as it is articulated in the third and fourth line of the sixth stanza. ${ }^{34}$ Consequently, the following two lines ('let me this way, quietly and gladly, trasp your rays and let you affect me') express another change of attention: They return to metaphysical contemplation that has merely been enriched by outer perception. In the seventh stanza, the lyric self appeals to God again: 'Mache mich einfältig, innig, abgeschieden [...]' ('make me simple, heartfelt, isolated'). After our soul has been purified, Tersteegen once wrote, 'God may well once grant us such holy delight (Divertissement) and promenade; yes, he may well lead us outside once to look at his depictions and illustrations, only to lead us back, then, inward to him, to contemplate the idea and essence of truth; and by going in and out like this with our Good Shepherd, we find pasture and food everywhere' (Op. cit. ibid.; my translation - M.S.).

Unquestionably, Tersteegen's depiction of nature shows a higher degree of individualization than Gerhardt's. But the actual object of individualization is not the natural, but its experience, whose qualitative content does not derive from the perception of nature as something incomprehensibly unique, but from inward mystical experience and its projection into the natural sphere. Like Gerhardt, Tersteegen expresses a spirituality that establishes a relation to God by means of the

34 According to Ludewig, the development of the song corresponds to the biographical development of Tersteegen's piety. 'In his later years', says Ludewig, he found 'a noticeably positive attitude toward nature' (Ludewig 1986, 205; my translation - M.S.). 
dialectic between emotional inner-directed and other-directed self-relation. I would like to compare Tersteegen's text with another poem now, which prima facie seems to show no affinities to Tersteegen's inwardness. Again my discussion of the following text serves to paradigmatically exemplify religiously determined attitudes toward natural experience in the context of the Arndtian tradition of Protestantism.

\title{
4 "In a reflective mood I saw": Barthold Hinrich Brockes and the rational explanation of nature
}

\author{
The poem I would like to focus on is Barthold Hinrich Brockes' Kirschblüte bei der \\ Nacht. ${ }^{35}$ This is the complete text ${ }^{36}$ :
}

35 Brockes was born in Hamburg in 1680 as the son of a wealthy merchant. From 1691 to 1697 he went to the "Gelehrtenschule des Johanneums," therafter to a college prepatory school. He studied law in Halle (a.d. Saale), then traveled extensively through Italy (1703) and continued his journey going to Geneva, Lyon, Paris, Brussels, Antwerp and Leiden, where he received a law degree. In December 1704 he returned to Hamburg. He married Anna Ilsabe Lehmann, the daughter of a merchant in Hamburg, and had twelve children (of whom four died before reaching their 18th birthday). In 1720 he was elected senator of Hamburg. For diplomatic affairs he met the kings of Denmark and Prussia and the Palatinate Prince of Hanover. Brockes wrote several librettos and founded the Teutsch-übende Gesellschaft in Hamburg. He was elected poeta laureatus by the German emperor for poetry published between 1721 and 1748 in nine volumes (the last one post mortem) under the title Irdisches Vergnügen in Gott. Brockes died as a well-acknowledged patrician of Hamburg in 1747 and was buried in St. Nicolai. On Brockes' position between early Enlightenment and Protestant theology Chraplak 2015. On the relation between the sacred and the secular in Brockes' poetry cf. Fry 1990, on Brockes' position within the history of natural lyrics cf. Peters 1993 (with specific reference to Brockes' flower-poetry). On the sublime in Brockes' poetry cf. Zelle 1990.

36 A paraphrase of the contents of what follows (translation according to https://sites.google. $\mathrm{com} /$ site/germanliterature/18th-century/brockes [hit 30th of July, 2018]): In a reflective mood I saw / recently a cherry tree in blossom / on a cool night by moonlight; / I thought nothing could be more white. It was as if snow had fallen; / every branch, even the smallest, / carried a full and equal load / of delicate white round balls. / No swan is this white, for on each petal / -since the moon's soft light / permeates the delicate leaves - / even the shadows are white and without blackness. / Impossible, I thought, that on earth / anything whiter could be found.

Then as I wandered here and there / in the shadow of this tree / by chance I looked up / through all these blossoms into the air / and I witnessed a still whiter light / a thousand times so light, so clear, / so astonishing it almost bowled me over. / The snowy blossoms seemed almost black / set against this white gleam. A white light fell / into my face from a bright star / that shone right into my soul.

I thought as much as God delights me / in earthly things he has still greater treasures. / The greatest beauty of this earth / cannot be compared with that of heaven. 
Ich sahe mit betrachtendem Gemüte

Jüngst einen Kirschbaum, welcher blühte, In kühler Nacht beim Mondenschein;

Ich glaubt, es könne nichts von größrer Weiße sein.

Es schien, ob wär ein Schnee gefallen.

Ein jeder, auch der kleinste Ast

Trug gleichsam eine schwere Last

Von zierlich weißen, runden Ballen.

Es ist kein Schwan so weiß, da nämlich jedes Blatt,

Indem daselbst des Mondes sanftes Licht

Selbst durch die zarten Blätter bricht,

Sogar den Schatten weiß und sonder Schwärze hat.Unmöglich, dacht ich, kann auf Erden

Was Weißers angetroffen werden.

Indem ich nun bald hin, bald her

Im Schatten dieses Baumes gehe,

Sah ich von ungefähr

Durch alle Blumen in die Höhe

Und ward noch einen weißern Schein,

Der tausenmal so weiß, der tausendmal so klar,

Fast halb darob erstaunt, gewahr.

Der Blüte Schnee schien schwarz zu sein

Bei diesem weißen Glanz. Es fiel mir ins Gesicht

Von einem hellen Stern ein weißes Licht,

Das mir recht in die Seele strahlte.

Wie sehr ich mich am Irdischen ergetze,

Dacht ich,hat Gott dennoch weit größre Schätze.

Die größte Schönheit dieser Erden

Kann mit der himmlischen doch nicht verglichen warden (Brockes 1992 [1721/48], 38).

The first stanza of the poem evokes a situation of spontaneous contemplation whose objects are the blossoms of a cherry tree under a full moon. ${ }^{37}$ The past tense of the text indicates that the lyric self is retrospectively evoking a past experience. In the first four lines it communicates its utmost astonishment about the

37 The poem does not mention a full moon, but we have to presuppose it, otherwise the effect of the blossoms would not be physically believable. 
perceptual impressions caused by the cherry blossoms. Their whiteness is said to have transcended everything the lyric self has experienced so far (cf. line 4). The following four lines specify the phenomenon in question; the next four lines deliver an explanation for its cause, before the stanza ends in the last two lines with a confirmation of the phenomenon's outstanding character. The specification of the phenomenon as well as its explanation are framed by the lyric self's asseveration that the characteristic properties of the cherry blossoms overwhelm the power of comprehension. Their whiteness on that very night was not just whiter than the usual appearance of this colour 'on earth', it was outstanding. And although the lyric self undertakes a close rational investigation of the phenomenon - which proceeds by careful and detailed observation and results in a 'causal theory', according to which it was the particular mode of light radiated by the moon that created the stunning effect ${ }^{38}$ - the rational act of comprehension surrenders to the impression. Impossible, the lyric self concludes, to find anything on earth that could be even whiter!

Indeed, the analytical description and causal explanation of natural phenomena hardly serve the sufficient representation of these phenomena in Brockes' poems. The poet writes about nature in the tradition of the liber naturae cosmology; and the objects observed always reveal a higher order than the merely functional one, which we may define in physical terms. ${ }^{39}$ But usually an admission of nature's incomprehensibility refers either to its teleological complexity, presupposing a principally understandable finality, ${ }^{40}$ or to the aesthetic 'drama'

38 Cf. line 10 and 11: 'Indem daselbst des Mondes sanftes Licht / Selbst durch die zarten Blätter bricht [...] (since the moon's soft light permeates the delicate leaves).' Kirschblüte bei Nacht gives a rather modest example of Brockes' rational way of looking at nature. The poet often displays a 'rational matter-of-fact style', which often enough proceeds according to an order that is demonstrated by 'the succession of theorem, proposition, line of reasoning and inference', as Wolfgang Martens has shown in reference to his poem Die Heide (Martens 1989, 269, 266; my translation - M.S.). 39 On the tradition of the Book of Nature and Brockes' adaptation of Arndt's Wahres Christentum and Christian Scriver's book Seelenschatz cf. Fry 1990, 252-69.

40 In Das Blümlein Vergissmeinnicht, Brockes clearly articulates his confidence that man - a proper, namely pietist, mind presupposed (cf. Brockes' first stanza of his poem Die Welt (Brockes 1992 [1721/48], 18)) - may successfully read (in) the Book of Nature: 'In so viel tausend schönen Blättern / Aus dieses Weltbuchs A B C / So viel, so schön gemalt, so rein gezogne Lettern, / Daß ich, dadurch gerührt, den Inhalt dieser Schrift / Begierig wünschte zu verstehn. / Ich konnt es überhaupt auch alsbald sehn / Und, daß er von des großen Schöpfers Wesen / Ganz deutlich handelte, ganz deutlich lessen' (Brockes 1992 [1721/48], 77). The following stanza from Die Welt does not contradict this confidence: 'O unbegreiflichs Buch! O Wunder-A B C! / Worin als Leser ich und auch als Letter steh'!' (ibid., 21). The wonders of nature may factually never be fully comprehended by us, but only because we are always restricted by a partial perspective on the whole, of which we are part. Brockes would never question the fact that nature is principally 
of natural events, which mysteriously show the harmony of its elements and thereby indicate their baffling finality, ${ }^{41}$ or it even refers to the teleological faculty of perceiving the natural order through its delightful appearance. But incomprehensibility is seldom described as a single 'secondary quality' as such that is said to be outstanding as it is in Kirschblüte bei der Nacht. You may hardly find a more significant example for the principal surrender of rational explanation to the 'wonders' of nature than in this poem, since the incommensurability of the perceived object is not at all explicable in teleological terms. Neither is the fascinating object fascinating as something mysteriously teleological, nor as something that mysteriously illustrates the finality of the natural order. It is simply fascinating as something that is mysteriously white, whiter than anything that has ever been white before.

The fact that we are not likely to find anything 'on earth' whiter than these cherry blossoms even prepares an outbidding of the superlative. While casually strolling in the tree's shadow - caused by the 'gentle' moonlight, we may suppose - the lyric self, as it reveals to us in the second stanza, becomes aware of an even whiter white, something so indescribable that Hermann Glaser called it rather enthusiastically a 'super-white infinity' (Glaser 1980, 25-7). Indeed, this white - the lyric self is talking about a 'bright star' (st. 2, line 10) - is not from this world, it is literally extraterrestrial and therefore evokes the idea of the infinite in us that we usually associate with the common features of the universe. What Walter Benjamin said about the aura of natural objects - that they were 'the unique appearance of something distant, no matter how close it might be ${ }^{\mathbf{4 2}}$ - surely characterizes the lyric self's impression of the cherry blossoms. But even more so it fits to the perception of the starlight. In both cases, a metaphorical meaning of 'distance', illustrating the incomprehensibility of the aesthetically experienced object, may stand for the colour; but in the second case even the literal meaning of distance is appropriate: The star's colour is from another actual world, a world

comprehensible, and he even thinks, again, that we are also principally capable of comprehending, as long as we as true believers transcend our partial perspective: 'Laß grosser Schreiber!', the stanza continues, 'mich im Buche dieser Erden / Zu Deines Namens Ruhm / ein lauter Buchstab werden!'.

41 Let me exemplify this by a stanza out of Die Sonne, which deals with sunrise: 'Drauf erzeugt dein Glanz und bildet / Farben, Morgenröt und Tau, / Malt, bepurpurt und vergüldet / Das gemischte Silbergrau, / Und der Himmel scheint ein Schleier, / Der aus Rosen, Gold und Feuer / (Von der Luft Saphir bezirkt) / Wunderbarlich schön gewirkt' (Brockes 1992 [1721/48], 117).

42 According to Benjamin, we define the aura of natural objects 'als einmalige Erscheinung einer Ferne, so nah sie sein mag'. His example: 'An einem Sommernachmittag ruhend einem Gebirgszug am Horizont oder einem Zweig folgen, der seinen Schatten auf den Ruhenden wirft das heißt die Aura dieser Berge, dieses Zweiges atmen' (Benjamin 1980 [1935], 479). 
that is infinitely far away. And although the lyric self rather dryly remarks that it was 'almost half astonished' by that sight (st. 2, line 7), we are not puzzled by the fact that this light emotionally arouses the self, as it openly admits in the last line of the second stanza. Maybe after the surprise of the cherry blossoms nothing can really increase its astonishment anymore. The fact is that the light shines into the self's soul in the same way it was sought to 'touch the face' of Tersteegen's lyric self and would have warmed the 'heart' that is addressed in Gerhardt's poem.

In Brockes' text, we actually seem to find what we missed in Tersteegen's and Gerhardt's church songs: the conceptualization of the natural as something that may surprise us by its qualities. The cherry tree clearly does not serve the lyric self as a mirror of religious projections; it therefore does not seem to be the external, yet integral part of a pietist self-relation. In Kirschblüte bei der Nacht the lyric self is not oriented inwardly - just the opposite: it is overwhelmed by something unexpected, which awakes its curiosity. The rational investigation, anticipating the great spirit of the naturalist societies which rise in the later half of Brockes' and the beginning of the following century, proves this curiosity. We would expect, now, to find the lyric self in the third stanza praising the Lord for the wonders of nature, which so astonishingly outrule its power of comprehension and surprise it with ever new qualities. But irritatingly the opposite is the case: The contemplation of the starlight makes the lyric self conscious of God's even 'greater treasures' that it cannot become aware of sensuously. How is this sudden change of mind possible? Why does the self, after the cherry blossoms and the starlight have evoked the idea of the infinite, of the superior, turn away from nature and deny its impression by minimizing it in relation to the wonders of God?

The prima facie interpretation is as follows: Brockes 'stages' the increase in beauty from the terrestrial blossoms to the extraterrestrial starlight because he wants to introduce us to an allegorical meaning. The starlight is a sign for the heavenly beauties, which are incomparably greater than the earthly ones. The lyric self reads this sign correctly, and with him so do we. But I do not think that this interpretation is appropriate to the text. Let us therefore take a look again at what was happening in the summer night we read about. Let us suppose that the poem reconstructs an experience. Let us suppose that it is really about someone walking around in a mild early summer night and suddenly becoming aware of the incommensurable materiality of whiteness that characterizes cherry blossoms in full moonlight. In my opinion it would not make any sense to suggest that this person, by accidentally focusing on the stars, ${ }^{43}$ would abruptly

43 Brockes makes it quite clear that the change of focus is accidental: 'Indem ich nun bald hin, bald her [...] gehe/ Sah ich von ungefähr [...]' (Then as I wandered here and there ...). 
shift from immediate sensuous perception to allegorical reflexion. It would not make any sense to presuppose that the self originally intended the starlight as an allegorically meaningful object referring to the treasures of Heaven. That would not be plausible for the simple fact that within the logic of the very experience articulated there is a 'primacy of perception' over understanding. The starlight, if intended accidentally, would first have to be perceived in the same way the cherry blossoms had become subject to the lyric self's attention. More precisely, the experience must have proceeded in the following way: The self, attentionally occupied with the whiteness of the blossoms (1), continued its walk and caught the stimulus of some other 'whiteness' (2), on which it then intentionally focused (3), identified as a star (4) and succeeded to compare with the whiteness of the previously perceived blossoms (5), before it finally ascribed an allegorical meaning to it (6), which it retrospectively articulated according to the dichotomy of 'earth' vs. 'Kingdom of Heaven' (7). The allegorical understanding is the final result of an experience that is based on the primacy of non-allegorical perception.

What follows from this? Simply that the cherry blossoms and the starlight originally belong to the same, namely the physical, sphere. The allegorical interpretation displayed in the third stanza does not represent a previous 'allegorical perception' ${ }^{44}$ And therefore it does not represent an astonishment that derives from the allegorical meaning of the perceived object. The lyric self's excitement is directly linked to the primordial (non-allegorical) perception of the starlight. The third stanza represents a thought (st. 3, line 2: 'Dacht ich') that has been motivated by the perception of the 'super-white infinity' (Glaser). We already encountered this thought in the 9th stanza of Gerhardt's song, in which the lyric self also 'thinks' that the Kingdom of Heaven must be indescribably (more) beautiful, since God had already created so much beauty in our world..$^{45}$ But we have to consider that Gerhardt's 'point of departure' differs from Brockes'. Whereas Gerhardt's poem indicates the primacy of inner-directed self-relation, Brockes' 'enlightened' self seeks to still the curiosity which has been evoked by the unpredicted quality of superior whiteness. Brockes' lyric self is not encouraged to seek

44 Principally 'allegorical perception' is possible. This would mean that with the prerequisite of the according dispositions something is spontaneously perceived as representing an absent entity. Exactly this is not the case with Brockes' lyric self in Kirschblüte bei Nacht. It perceives an astonishing whiteness, 'an even whiter glance', before it can identify this as the appearance of a star whose exceptional brightness may serve allegorical purposes.

45 'Ach, denk ich, bist du hier so schön / Und lässt du's uns so lieblich gehen / Auf dieser armen Erden: / Was will doch wohl nach dieser Welt / Dort in dem reichen Himmelszelt / Und güldnem Schlosse werden!' (Ah, I think, if you are so beautiful here and show and show us such lovely sights on this poor earth, how wonderful it would be, after this world, there in the rich heavens and life in the golden palace). 
the relation to its God in an other-directed self-relation which is defined by clearly determined dispositions. Brockes' lyric self is simply outdoors. It happens to find itself wandering around. It does not project, it curiously perceives.

Therefore, the thought of the lyric self, which we get to know in the third stanza, is not motivated immanently by the development of the poem. After the lyric self has enthusiastically surrendered to the incommensurable impressions of blossoms and starlight, it suddenly and mysteriously denies the sensuous evidence of natural greatness in the name of intelligible, clearly non-sensuous evidence. Denied is not only the primordial impression of the cherry blossoms, but also the primordial and non-allegorical impression of the starlight, in so far as both belong to the empirical sphere of sensuous perception. They could not be compared, as the lyric self claims, to heavenly beauty. The starlight may only serve to illustrate the 'much greater treasures' as an allegorical sign, as a stimulus for metaphysical contemplation. But as the natural source of sensuous and incommensurable impression, its quality is denied. The surrender of the rational observer to the incommensurable beauty of the natural sphere, whether terrestrial or extraterrestrial, which the self attentionally became aware of, is finally turned into the opposite: the surrender of natural beauty to the greater one of intelligible entities, which - as we must add - are not sensuously perceivable, but reveal themselves inwardly.

We see now that Brockes' poem finally re-establishes the relation to nature as an other-directed self-relation - which was also expressed in Gerhardt's and Tersteegen's poems and which we find in many of Brockes' poems. But whereas in the case of Gerhardt and Tersteegen it was made plausible as an internal aspect of a primarily inner-directed self-relation, Brockes' text starts out rather differently. It does not allude to any sort of inward contemplation or even unio with God. Instead the self is originally set into the openness of unpredictable sensuous perception. Only the apodictic judgment in the third stanza hints at the fact that every aesthetic relation to nature is an other-directed relation to God in me and that it is subordinate to the relation I can directly establish with the Creator. ${ }^{46}$ How do our results make sense in relation to the concept of the sublime?

$46 \mathrm{~J}$. A. H. Reimarus has handed down to us that Brockes - similar to the logic of the piety of nature displayed in Tersteegen's text - used to begin his service in nature with the service in church (Strauß 1876, 8). 


\section{The inward sublime}

First of all, none of the three poems discussed deal with the kind of natural phenomena which Burke or Kant would call candidates for the sublime. Gardens, particularly flowers, and more so 'secondary qualities' such as colours are neither mathematically nor dynamically sublime. They are of no incommensurable extension, they do not come with any vagueness or obscurity that may create unease in us, and they certainly do not appear to us as a potentially dangerous power. Instead, they are simply beautiful. Still, we may find traces of the sublime in Tersteegen's text. Whereas Gerhardt's Geh aus, mein Herz is restricted - in Kant's words - to the sphere of aesthetic and teleological finalities, Tersteegen's Gott ist gegenwärtig clearly goes beyond it. But he does not do so in the sixth stanza, where he refers to the natural world (namely the 'gentle flowers'), but in the fifth, in which the lyric self circumscribes the unio with God within the inner-directed self-relation. 'Air' and 'sea' are characterized in their incommensurable extension ('air that fills everything', 'sea without bottom and end'). But here they serve as metaphors for the 'sublimity' of God in us. And obviously the powerful might that we associate with the sea (and with the air, where we do not try to visualize oxygen, but the open sky and wind) does not create unease in the lyric self, because it actually intends to 'disappear' into this might. The attribution of unease (or horror) to the experience of the sublime presupposes the will to resist and to maintain autonomy, but exactly this is not the case in mystical contemplation. In Tersteegen's song, the mystical relation to God via inner-directed self-relation is characterized in terms of the sublime. But it is the inward sublime, which in the following stanza prepares the lyrical self to contemplate natural beauty.

Brockes' text, like Gerhardt's, does not reveal any traces of the sublime. The cherry blossoms as well as the starlight are referred to as beautiful (indirectly in st. 3, line 3), and indeed both would not fulfil the criteria of sublime objects. In fact, according to Kant their outstanding whiteness would not even be called beautiful in the strict sense of the word, as it is defined by the validity claim of an aesthetic judgment. Mere 'secondary qualities' such as colours may evoke a 'positive emotional reaction of the subject in his relation to the world' (Kulenkampff 1978, 75; my translation - M.S.). But this emotional reaction, according to Kant, defines the agreeable, not the beautiful. Agreeability is neither a sufficient nor even a necessary condition of an aesthetic judgment that evaluates the beautiful, because beauty, in Kant's terms, is a function of the interplay of our cognitive powers, engaging our imagination and the epistemic categories of quantity, quality, modality and relation. Thus, an object is beautiful if it is final to 
this interplay, not just emotionally agreeable. ${ }^{47}$ But certainly the praised whiteness in Kirschblüte bei der Nacht fulfils Burke's criteria of the beautiful, which differ substantially from Kant's concept. By beauty, Burke means 'that quality or those qualities in bodies by which they cause love, or some passion similar to it' (Burke 1990 [1757], 83), and he clearly stresses that beauty is no matter of proportion - as Kant's finality of the beautiful object to our cognitive powers surely is and therefore 'demands no assistance from our reasoning; [...] the appearance of beauty as effectually causes some degree of love in us, as the application of ice or fire produces the ideas of heat or cold' (ibid., 84).

Burke's definition of the beautiful yields to those characteristics that Kant exclusively ascribes to the sublime, namely the incommensurability and/or incomprehensibility of the aesthetic object. And he puts emphasis on the possible suddenness which may accompany the perception of beauty. This definition fits perfectly to the experience of the lyric self in Brockes' poem. The whiteness of blossoms and starlight surprises the attentionally perceiving self, who repeatedly stresses the incommensurability of the perceived. The whiteness resists the self's 'causal theory' about the physical origin of the stunning impression and therefore proves to be incomprehensible. By minimizing the physical beauty in relation to the metaphysical, yet non-sensuous, beauty, Brockes denies the exceptionality of an appearance that is particularly characterized by effects on the perceiver namely incommensurability and incomprehensibility - which Kant ascribes to objects commonly called 'sublime'. ${ }^{48}$ Therefore it will be interesting to see how Brockes deals with the sublime in the strict sense of the word. Let us take a look at a stanza in his poem Die Sonne:

Siehet man des Meeres Breite,

Muß man nicht erstaunt gestehn,

Daß die ungeheure Weite

Fast entsetzlich anzusehn?

Dennoch schwimmt, samt dem Gefäße,

47 On the difference between the agreeable and the beautiful, cf. Kulenkampff 1978, 75-8; Früchtl 1996, 69-71. Früchtl points out that aesthetic judgment is to be located somewhere between determinant experience judgment and mere perception judgment, and suggests calling it a third order-perception judgment - which is a judgment about the agreeable object that can be generalized, since it abstracts from the mere agreeability of the object in favour of its finality to our cognitive powers.

48 According to contemporary aesthetic theories, we may even have some reason to ascribe sublimity to the phenomena in question. At least prima facie there seems to be an affinity between the 'super-white infinity' in Brockes' poem and monochrome paintings, which Lyotard refers to as examples of the sublime in modern art. 


\section{Dieses Weltmeers Tief und Größe \\ In der Sonnen Meer von Glut \\ Wie ein Tropf im Weltmeer ruht}

(Brockes 1992 [1721/48], 116, stanza no. 45). ${ }^{49}$

The stanza clearly refers to the natural sublime. But - unlike the first two stanzas in Kirschblüte bei der Nacht - it does not take the personal perspective. It wants to prove a general point about the sublime in nature, as the impersonal form in the first line ('If one sees the width of the ocean') shows. First it refers to the ocean's 'enormous expanse' that is 'almost terrible to look at'. This is reminiscent of Burke $(1757,53)$ ascribing the effect of terror to the sublime. The reservation of its being almost terrible creates the impression of a defensive attitude toward the object by trying to play down what actually would be overwhelming. 'Nevertheless', the stanza continues, the ocean and the planet that contains it swim in the glow of the sun. The overwhelming features of nature, which are exemplified by the attributes of the ocean rather than precisely observed, are neutralized by something even larger that is brought into play. The ocean is described as small compared to the sun, no matter how large and terrible it may appear at first. Now, it may seem that one case of the natural sublime has simply been just outdone by another case that arouses our sentiments even more intensively. But from the beginning of the poem it is clear that the sun serves an allegorical function: it pictorially illustrates a metaphysical truth. No immediate and unpredicted perception is articulated, as it is in Kirschblüte bei der Nacht. Instead, Die Sonne is a hymn on a star, and the depiction of its sublime properties as well as their sublime effects on the world - which, by the way, are not said to create the least feeling of terror in us, although its dominating might is clearly admitted in several stanzas - serve as symbols in the worship of God. The approach therefore is neither motivated by a sudden phenomenal surprise nor by the curiosity of the natural scientist who wants to understand the astonishing. In short: it is not phenomenological like in many of Brockes' other poems, including Kirschblüte bei der Nacht. It is allegorical from the start. The hymn-like appeal to the sun serves as a 'bridging principle' to turn the reader's attention to the godly properties and the praise of the Creator. The poem is a praise of God mediated by the praise of the sublime sun. It stimulates our respect for the infinite, the eternal and the mighty in us, which brings us to the actual inhabitant of these attributes. It expresses

49 If one sees the width of the ocean, doesn't one have to astonishingly admit that the tremendous vastness is almost appalling to look at? Nevertheless, this ocean's depth and size floats with its vessel in the sun's sea of blaze like a driblet rests in the ocean. (My translation - M.S.) 
a relation to God by means of an other-directed self-relation. ${ }^{50}$ Clearly the sun's incommensurable and incomprehensible greatness, since it illustrates the metaphysical greatness of God, is thought to be a faint image of the latter, which is non-imaginable. Therefore it is denied (by minimizing it) after it has successfully done the job of 'leading' us to God:

\author{
Edle Quelle güldner Klarheit, \\ Deine Größe, Kraft und Pracht \\ Zeigen uns die große Wahrheit, \\ Daß der Gott, der dich gemacht \\ Unbeschreiblich schöner, größer, \\ Unaussprechlich heitrer, bessrer, \\ Unbegreiflich herrlicher, \\ Höher und gewaltiger
}

Let me summarize: Tersteegen, as well as Brockes, ascribe predicates of the sublime primarily to God whom we, again, primarily sense inwardly. The contemplation of nature may evoke our idea of God and our feelings for him in us, because it refers to him, but it does so in a rather platonic mode: like a faint image of the original idea. Just as we must know the original idea to be capable of identifying something as its (faint) image, the relation to God by means of an other-directed self-relation is founded in a relation to God that is established by an inner-directed self-relation. In Gerhardt's texts, as well as in Tersteegen's and Brockes', we can detect the conceptualization of nature as an integral element of the pietist self-relation. Here, nature is subject to the disposition of seeing 'outside', what is felt 'inside'. The way nature is perceived reflects states of consciousness which are caused by inner stimulation. But Brockes' Kirschblüte bei der Nacht exemplifies a disposition that goes clearly beyond this. The objects (blossoms and starlight) attentionally perceived surprise, dazzle the perceiver, whose disposition toward nature is based on curiosity for the new, for the unknown and non-predicated - let it be cherry blossoms or

50 Cf. the 56th stanza: 'Wenn man, was wir hievon lesen, / Und, was glaublich ist, erwägt, / Welch ein majestätisch Wesen / Gott der Sonne beigelegt, / Was für Macht er drin gesenket, / Ruft mein Herz, das dies bedenket: / Welch ein König! Welcher Thron! / Welch ein Reich und welche Kron!' ('If we consider ... what a majestic nature God has given to the sun, the might He has bestowed her with, then my heart, while contemplating all of this, exclaims: What a King, what kind of throne, empire and crown'; my translation - M.S.).

51 Noble source of golden clarity, your size, power and splendour show us the great truth, that this God who made you, is indescribably more beautiful, greater, ineffably more cheerful, better, incomprehensibly more glorious, much higher and tremendous. 
flies or whatever natural object the wanderer may run into in Brockes' poems. But it is also guided by an eagerness to explain it. In the end, however, this disposition is not carried through the whole process of the articulated experience. The factual incommensurability and incomprehensibility of the perceived as such - whether it repels the perceiver or not ${ }^{52}$ - makes her turn to a metaphysical contemplation of these characteristics and evaluate the actual stimulus of this contemplation as minor to the intelligible content of what is perceived. The factual incommensurability and incomprehensibility of the natural object is minor to the ideas of incommensurability and incomprehensibility, which are part of our contemplation of God and the 'Kingdom of Heaven'. Incommensurability and incomprehensibility are central features of the sublime. Brockes' poem Die Sonne confirms the logic of reinterpreting natural phenomena, as was displayed in the final stanza of his Kirschblüte bei der Nacht: The factual sublime is minor to the idea of sublimity, which is originally stimulated by the former and which is part of our contemplation of God. The natural sublime is surpassed by the inward sublime.

\section{Kant's aesthetics and the Protestant tradition}

Let us finally return to Kant. I previously argued that the particular form which his theory of the sublime takes cannot be explained merely in terms of systemic coherence and historical reference - whether critical or affirmative - to predecessors. I argued that it had to be understood as an Ausdrucksgestalt, an expressive articulation of empractical patterns of understanding, which originate from the Arndtian tradition of Protestant piety. But I also restricted the 'empractical' to a heuristic concept, whose plausibility depends on empirical evidence, i.e. on the results of the foregoing interpretations. According to these results, Gerhardt, Tersteegen and Brockes are different, though structurally related, examples of the inward worldview, whose concept of nature is determined by an other-directed self-relation, which derives from an inner-directed self-relation. The poems analysed display this other-directed self-relation without explicitly dealing with it. The other-directed self-relation is expressed in the way the poems semantically make sense of their

52 Hans Blumenberg characterizes Brockes - not very charmingly, but trenchant - as an 'honest' poet, who displays a 'homely' attitude toward the world and was 'pedantically busy' to teach us the wonders of creation. He calls Brockes' Irdisches Vergnügen in Gott an edificatory book for the 'placid senses' of the bourgeois (cf. Blumenberg 1986, 180, 181, 182). The incomprehensible, particularly the sublime, despite its fascination may very well have repelled a character like Brockes. 
topics; it determines - again borrowing Bourdieu's words - the modus operandi of the opera operata, which have been discussed. Another opus operatum, expressing a worldview that has been shaped by the inward tradition of Protestant pietism, is Kant's 'Analytic of the Sublime'. It is the philosophical transformation of the inward sublime we found in the previously interpreted texts, particularly of an attitude toward aesthetic incommensurability and incomprehensibility, which Brockes displays in Kirschblüte bei der Nacht. Let me once again refer to one of Kant's central passages that clearly locates the sublime inwardly and interprets the outward sublime as a comparatively insufficient presentation of the inward: 'All that we can say is that the object lends itself to the presentation of a sublimity discoverable in the mind. For the sublime, in the strict sense of the word, cannot be contained in any sensuous form, but rather concerns ideas of reason, which, although no adequate presentation of them is possible, may be excited and called into the mind by that very inadequacy itself which does admit of sensuous presentation' (Kant 1953 [1790], 92). But the fact that a specific sensuously perceived object may present the inward is not simply arbitrary. The 'substitution of a respect for the Object in place of one for the idea of humanity in our own self' (ibid., 106) has a fundamentum in re. The object is incommensurable, it is incomprehensible: it does not just seem to be so. But this substitution is only possible under the condition that we are already acquainted with the ideas of the incommensurable and incomprehensible, which as such - as ideas - may clearly be comprehended by thinking them (cf. ibid., 115). Our awareness of the gap between what may be perceived and what may be thought, i.e. 'the feeling of the unattainability of the idea by means of the imagination, is itself a presentation of the subjective finality of our mind in the employment of the imagination in the interests of the mind's supersensible province, and compels us subjectively to think nature itself in its totality as a presentation of something supersensible, without being able to effectuate this presentation objectively' (ibid., 119). 'Thinking nature', which arouses our restricted faculty of imagination, is nothing else but an invitation to its allegorical interpretation; Kant, too, stands in the tradition of the Book of Nature.

But, of course, the meaning that is allegorically understood by thinking nature as presenting something supersensible to us differs substantially from the poets' understanding of the matter. Kant gets rid of all ontological claims regarding the supersensible, whose awareness is being aroused by nature, and he is sceptical about its personalization as God. From a subjective standpoint, he writes in Die Religion innerhalb der Grenzen der bloßen Vernunft, religion is the recognition of all our duties in terms of godly commandments (Kant 1998 [1793], 822). The validity of these duties does not derive from their supposed godly origin because this origin is a mere hypothesis. It derives from our consent to them, because as rational beings belonging to the 'space of reason' (Sellars), we are intrinsically forced to 
agree upon them. For various practical reasons, we may (and even should) represent these duties as godly commandments. But this practical acknowledgement does not have any ontological consequences, nor is it based on such. Kant argues similarly about the sublime. Whereas the discussed poets seek the contemplation of God by means of the perception of nature, Kant seeks the stimulation of ideas, the dignity of which derives from the mere fact that we are capable of thinking them. We may represent those ideas, of which we become aware through the supposedly sublime in nature, as attributes of God, but this personalization does not represent any ontological knowledge. What we actually become aware of with the utmost certainty is our faculty of thinking the infinite, the eternal, the almighty. And whereas Brockes, Tersteegen and Gerhardt were also and even primarily aware of God by means other than the contemplation of nature, according to Kant we have an internal faculty which enables us to think the supersensible without any reference to the 'outer' world. All three of those poets presuppose a relation to something supersensible by means of an inner-directed self-relation, which integrates an other-directed self-relation. But within the Protestant tradition of piety, the correlated 'other' within this inner-directed self-relation is understood as God ('in us'); whereas Kant conceptualizes it as ideas, which on the one hand are generated by our individual activity of thinking (thereby being 'in us', so to speak), but on the other hand transcend this activity by their objective, i.e. logical validity.

In as far as the natural sublime makes us aware of our intelligible faculty, it is functionalized for the inner-directed self-relation of rational beings. We may think the noumena without being aware of thinking them. But then the natural sublime puts us in a state of 'monitoring' our faculty of thinking, thus making us aware of our superiority over the phenomenal sphere. Particularly the dynamically sublime has a practical impact on our everyday life, since it is predestined to arouse the awareness of a moral vocation in us that is superior to all sensible motivations of our actions. At one point, Kant claims that we generally say of a man 'who remains unaffected in the presence of what we consider sublime, that he has no feeling' (ibid., 116). But according to his argumentation, we may also say that being affected by the so called natural sublime causes a feeling in us. It is a feeling for our moral commitments as rational beings and their superiority over the phenomenal sphere, and it is conveyed by the confidence that we - as rational, as moral beings - may prevail over (our) nature. Consequently, it is psychologically important in everyday life because it helps the individual who has become entangled in his ordinary affairs to (ever again) sensuously discover his supersensible vocation as a subject (cf. Früchtl 1996, 481-90). According to Kant's theory, the awareness of our faculty of thinking seems to make our normative commitments valuable to us. We are supposed to intrinsically follow our vocation, but the fact that we confidently do so, although we are factually more likely disposed to fail, seems to be based on 
the fundamental satisfaction we gather from consciously thinking the noumena. Otherwise it would not make any sense to associate any sort of attraction with the sublime because the attraction merely derives from the attention it draws to our own faculty of thinking the (specifically practical) ideas. Thinking them seems to result in evidence that not only forces practical consequences on us, but also makes them valuable to us. ${ }^{53}$ The ideas are valuable as the outcome of inferential thought.

But how can our mere thought be the source of practical values that direct our actions? Following Kant's argumentation, the reader gets the impression that thinking the ideas seems to elevate us over ordinary life in a way similar to that of religious believers crossing the threshold from the profane to the sacred. For Kant, the 'sacred realm' is an inward sphere, too: we may be stimulated by nature to cross the threshold, but when we do so, we shut ourselves off from the phenomenal sphere. Kant does not explicitly point to the quasi-religious implications of his theory, but Schiller has clearly seen them. In Über das Erhabene, which he wrote as a sort of supplement to his Briefe über die ästhetische Erziehung des Menschen, the individual experience of the natural sublime, which he interprets within the framework of Kant's theory, is characterized in a way that resembles classical reports of conversion experiences. ${ }^{54}$ Indeed, the natural sublime is the source of 'conversion'. It is not a conversion to God, but to our vocation, ${ }^{55}$ which becomes sensible to us in moments of enthusiasm caused by nature. Nature may stimulate us to discover our vocation, but ultimately we discover it 'inside'.

53 The recognition of the moral law means both: the understanding of its inferential necessity and the respect we feel for it. Cf. Kant 1998 [1785], 28.

54 'Das Erhabene verschafft uns also einen Ausgang aus der sinnlichen Welt [...]. Nicht allmählich [...], sondern plötzlich und durch eine Erschütterung reißt es den selbständigen Geist aus dem Netze los, womit die verfeinerte Sinnlichkeit ihn umstrickte [...]. [...] so ist oft eine einzige erhabene Rührung genug, dieses Gewebe des Betrugs zu zerreißen, dem gefesselten Geist seine ganze Schnellkraft auf einmal zurückzugeben, ihm eine Revelation über seine wahre Bestimmung zu erteilen und ein Gefühl seiner Würde, wenigstens für den Moment, aufzunötigen' (Schiller 1992 [1801], 612). Bjørn K. Myskja emphasizes the moral significance of the sublime and he clearly sees its importance in initiating a conversion as a necessary condition for cultivating the character. Cf. Myskja 2002, 194-203, 216-23. Myskja's book offered a great deal of inspiration when writing this essay.

55 According to the phenomenological description of Kurt Goldammer, a conversion 'takes place when a new truth has been recognized, a new and deep dimension of the Sacred, of the will of God, has been disclosed and has led to an inner change, when a new path to salvation is found, when a new life begins [...]' (Goldammer 1960, 454-5; my translation - M.S.). In terms of Kant's philosophy of religion, we may say that indeed a truth is discovered, and indeed this discovery leads to an inner change and a new beginning in life. But the truth derives from the reasonable validity claim of our practical ideas, and it is contingent that we represent this truth as the will of God. By thinking the ideas and consequently acknowledging them as our guiding principles in life, we also take something like a path of salvation: it leads us to our 'Glückswürdigkeit' and our unanimity with ourselves. 


\section{References}

Addison, Joseph. 1965 [1711/12]. 'Pleasures of the Imagination.' In The Spectator (eds. J. Addison, R. Steel), vol. 3, ed. D. F. Bond, Oxford: Oxford University Press. 411-21.

Althaus, Thomas. 1997. 'Entstehen aus dem Widerspruch. Das pietistische Lied bei Gottfried Arnold, dem Grafen von Zinzendorf und Gerhard Tersteegen'. In Halle und das pietistische Lied, ed. G. Busch/ W. Miersemann, Tübingen: Franckesche Stiftungen. 241-254.

van Andel, Cornelius Pieter. 1976. 'Paul Gerhardt, ein Mystiker zur Zeit des Barocks.' In TraditioKrisis-Renovatio, Marburg: Elwert. 172-84.

Arndt, Johann. 1845 [1605/09]. Johann Arnd's ... sechs Bücher vom wahren Christenthum (1605-1609) nebst dessen Paradiesgärtlein (1612), ed. J. F. von Meyer. Frankfurt a.M.: Brönner.

Benjamin, Walter. 1980 [1935]. 'Das Kunstwerk im Zeitalter seiner technischen Reproduzierbarkeit.' In Gesammelte Schriften, vol. I.2, Frankfurt a.M.: Suhrkamp. 471-508.

Blumenberg, Hans. 1986. Die Lesbarkeit der Welt. Frankfurt a.M.: Suhrkamp. Bourdieu, Pierre. 1974. Zur Soziologie der symbolischen Formen. Frankfurt a.M.

Brecht, Martin. 1979. 'Philipp Jakob Spener und das Wahre Christentum', Pietismus und Neuzeit 4/1979. Göttingen : Vandenhoeck \& Ruprecht. 119-154.

Brecht, Martin. 1993. 'Das Aufkommen der neuen Frömmigkeitsbewegung in Deutschland.' In Geschichte des Pietismus, vol. 1: Der Pietismus vom siebzehnten bis zum frühen achtzehnten Jahrhundert, ed. M. Brecht, Göttingen: Vandenhoeck \& Ruprecht. 113-203.

Brockes, Barthold Heinrich. 1992 [1721/48]. Irdisches Vergnügen in Gott, ed. A. Elschenbroich, Stuttgart.

Bunners, Christian. 1993. Paul Gerhardt: Weg, Werk, Wirkung. Berlin: Buchverl. Union.

Burke, Edmund. 1990 [1757]. A Philosophical Enquiry into the Origin of our Ideas of the Sublime and Beautiful, ed. A. Phillips. Oxford: J. Dodsley.

Chraplak, Marc. 2015. B. H. Brockes' fröhliche Physikotheologie. Poetische Strategien gegen Weltverachtung und religiösen Fanatismus. Bielefeld: Aisthesis.

Francke, August Hermann. 1969 [1721]. 'Idea Studiosi theologiae.' In Werke in Auswahl, ed. E. Peschke, Berlin: Evangelische Verlagsanstalt.

Früchtl, Josef. 1996. Ästhetische Erfahrung und moralisches Urteil: Eine Rehabilitierung. Frankfurt a.M.: Suhrkamp.

Fry, Harold P. 1990. Physics, Classics, and the Bible: Elements of the Secular and the Sacred in Barthold Heinrich Brockes' 'Irdisches Vergnügen in Gott', 1721. New York/Bern/Frankfurt a.M.: Peter Lang Publishing.

Gerhardt, Paul. 1992 [1667]. Geistliche Lieder. Stuttgart: Reclam.

Goldammer, Kurt. 1960. Die Formenwelt des Religiösen: Grundrisse der systematischen Religionswissenschaft. Stuttgart: Kröner.

Gulyga, Arsenij. 2004. Immanuel Kant: Eine Biographie. Frankfurt a.M.: Suhrkamp.

Günter Peters. 1993. Die Kunst der Natur. Ästhetische Reflexion in Blumengedichten von Brockes, Goethe und Gautier. München: Fink Wilhelm.

Haufe, Eberhard. 1978. 'Das wohltemperierte geistliche Lied Paul Gerhardts.' In Paul Gerhardt: Dichter - Theologe - Seelsorger, ed. H. Hoffmann, Berlin: Evangelische Verlagsanstalt.

Hillenbrand, Rainer. 1992. Paul Gerhardts deutsche Gedichte: Rhetorische und poetische Gestaltungsmittel zwischen traditioneller Gattungsbindung und barocker Modernität. Frankfurt a.M: P. Lang. 
Hoffmann, Dieter. 1982. Der Weg zur Reife. Eine religionspsychologische Untersuchung der religiösen Entwicklung Gerhard Tersteegens. Lund: Almqvist \& Wiksell.

James, William. 1987 [1902]. The Varieties of Religious Experience. In Writings 1902-1910. New York: Library of America.

Joas, Hans. 1999. Die Entstehung der Werte. Frankfurt a.M.: Suhrkamp.

Kaiser, Gerhard. 1996. Aufklärung, Empfindsamkeit, Sturm und Drang. Tübingen/Basel: Francke.

Kant, Immanuel. 1953 [1790]. The Critique of Judgement, ed. J. C. Meredith, Oxford: Clarendon Press.

Kant, Immanuel. 1998 [1785]. Grundlegung zur Metaphysik der Sitten. In Werke in sechs Bänden, vol. IV, ed. W. Weischädel, Darmstadt: Wissenschaftliche Buchgesellschaft.

Kant, Immanuel. 1998 [1793]. Die Religion innerhalb der Grenzen der blossen Vernunft. In Werke in sechs Bänden, vol. IV, ed. W. Weischädel, Darmstadt: Wissenschaftliche Buchgesellschaft.

Kant, Immanuel. 1998 [1798]. Der Streit der Fakultäten. In Werke in sechs Bänden, vol. VI, ed. W. Weischädel, Darmstadt: : Wissenschaftliche Buchgesellschaft.

Kemper, Hans-Georg. 1981. Gottesebenbildlichkeit und Naturnachahmung im Säkularisierungsprozeß: Problemgeschichtliche Studien zur deutschen Lyrik in Barock und Aufklärung, vol. I/II. Tübingen: De Gruyter.

Kemper, Hans-Georg. 1987. Deutsche Lyrik der frühen Neuzeit, vol. 2: Konfessionalismus. Tübingen: M. Niemeyer.

Kemper, Hans-Georg. 1993. 'Vielsinnige "Blumen”-Lese: Zum literaturhistorischen Standort Gerhard Tersteegens', Pietismus und Neuzeit 19/1993. Göttingen: Vandenhoeck \& Ruprecht. 117-42.

Kemper, Hans-Georg. 1997. Deutsche Lyrik der frühen Neuzeit, vol. 6/I: Empfindsamkeit. Tübingen: De Gruyter.

Klemme, Heiner F. 1994. Die Schule Immanuel Kants. Hamburg: Meiner.

Kock, Manfred/ Thiesbonenkamp, Jürgen. Eds. 1997. Gerhard Tersteegen - evangelische Mystik inmitten der Aufklärung. Bonn: Rheinland-Verlag.

Krummacher, Hans Henrik. 1976. Der junge Gryphius und die Tradition: Studien zu den Perikopensonetten und Passionsliedern. München: Wilhelm Fink.

Kulenkampff, Jens. 1978. Kants Logik des ästhetischen Urteils. Frankfurt a.M.: Klostermann.

Lehmann, Hartmut. 1980. Das Zeitalter des Absolutismus: Gottesgnadentum und Kriegsnot. Stuttgart: Kohlhammer.

Ludewig, Hansgünter. 1986. Gebet und Gotteserfahrung bei Gerhard Tersteegen. Göttingen: Vandenhoeck und Ruprecht.

Mager, Inge. 1992. 'Gottes Wort schmecken und ins Leben verwandeln: Johann Arndts Schriftverständnis.' Jahrbuch für finnisch-deutsche Literaturbeziehungen 24/1992, Helsinki. 149-58.

Martens, Wolfgang. 1989. ‘Erbauliche Naturlyrik eines Aufklärers (B. H. Brockes).', In Literatur und Frömmigkeit in der Zeit der frühen Aufklärung. Tübingen: Niemeyer. 261-75.

Monk, Samuel H. 1960. The Sublime: A Study of Critical Theories in Eighteenth-Century England. Ann Arbor, Mich.: University of Michigan Press.

Myskja, Bjørn. 2002. The Sublime in Kant and Beckett: Aesthetic Judgement, Ethics and Literature. Berlin/New York: De Gruyter.

Frank, Manfred. 2002. Selbstgefühl: Eine historisch-systematische Erkundung. Frankfurt a.M.: Suhrkamp. 
Petrich, Hermann. 1914. Paul Gerhardt: Ein Beitrag zur Geschichte des deutschen Geistes. Auf Grund neuer Forschungen und Funde. Gütersloh: Bertelsmann.

Riesman, David. 1989. The Lonely Crowd: A study of the changing American character. New Haven: Yale University Press.

Schiller, Friedrich. 1992 [1801]. 'Über das Erhabene.’ In Werke in drei Bänden, vol. 2, ed. H. G. Göpfert, G. Fricke, Frankfurt a.M. 607-18.

Schilling, Heinz. 1988. 'Die Konfessionalisierung im Reich: Religiöser und gesellschaftlicher Wandel in Deutschland zwischen 1555 und 1620', Historische Zeitschrift 246/1988. München: Oldenbourg. 1-45.

Schlette, Magnus. 2003. 'Vollendung der Religion? Überlegungen zum religiösen Atheismus im 19. Jahrhundert.' In Atheismus und religiöse Indifferenz, ed. Chr. Gärtner et al., Opladen: Leske + Budrich. 41-74.

Schlette, Magnus. 2005a. 'Selbstverwirklichung durch Artikulation.' In Anthropologie der Artikulation, eds. M. Schlette, M. Jung, Würzburg: Königshausen \& Neumann. 160-205.

Schlette, Magnus. 2005b. Die Selbst(er)findung des Neuen Menschen: Zur Entstehung narrativer Identitätsmuster im Pietismus. Göttingen: Vandenhoeck \& Ruprecht.

Schmidt, Lothar. 1982. 'Hertz und Garten Zier: Paul Gerhardts “Sommergesang”.' In Gedichte und Interpretationen, vol. 1: Renaissance und Barock, ed. V. Meid, Stuttgart: Reclam. 285-302.

Schmidt, Martin. 1979. 'Johann Arndt.' In Theologische Realenzyklopädie, vol. IV, Berlin/New York: de Gruyter. 121-9.

Schneider, Hans. 1992. 'Johann Arndt als Lutheraner?' In Die lutherische Konfessionalisierung in Deutschland, ed. H.-Chr. Rublack, Gütersloh: Gütersloher Verlagshaus G. Mohn. 274-98.

Sommer, Wolfgang. 1988. Gottesfurcht und Fürstenherrschaft: Studien zum Obrigkeitsverständnis Johann Arndts und lutherischer Hofprediger zur Zeit der altprotestantischen Orthodoxie. Göttingen: Vandenhoeck \& Ruprecht.

Sommer, Wolfgang. 1999. 'Gottes Odem in der Schöpfung: Zum Bild der Natur bei Johann Arndt und Jakob Böhme.' In Politik, Theologie und Frömmigkeit im Luthertum der Frühen Neuzeit, Göttingen: Vandenhoeck \& Ruprecht. 206-26.

Spener, Philipp Jakob. 1979 [1687]. Natur und Gnade. In Schriften, vol. IV, ed. E. Beyreuther. Hildesheim/New York: G. Olms.

Stoeffler, F. Ernest. ${ }^{2} 1971$. The Rise of Evangelical Pietism. Leiden: Brill.

Strauß, Johann David. 1876. Gesammelte Schriften, vol. II. Bonn.

Tersteegen, Gerhard. 1927 [1729]. Gerhard Terstegen's geistliches Blumengärtlein inniger Seelen, nebst der frommen Lotterie, nach der Ausgabe letzter Hand berichtigt und mit einigen Zusätzen vermehrt, sammt dem Lebenslauf des sel. Verfassers. Stuttgart: J.F. Steinkopf.

Wallmann, Johannes. ${ }^{2} 1986$ a. Philipp Jakob Spener und die Anfänge des Pietismus. Tübingen: J.C.B. Mohr (P. Siebeck).

Wallmann, Johannes. 1986b. 'Johann Sebastian Bach und die "Geistlichen Bücher” seiner Bibliothek,' Pietismus und Neuzeit 12/1986. 162-81.

Wallmann, Johannes. 1990. Der Pietismus. Göttingen: Vandenhoeck \& Ruprecht.

Wallmann, Johannes. 1995. 'Johann Arndt und die protestantische Frömmigkeit: Zur Rezeption der mittelalterlichen Mystik im Luthertum.' In Theologie und Frömmigkeit im Zeitalter des Barock, Tübingen: Mohr, J.C.B., (Paul Siebeck). 1-19. 
Weber, Edmund. 1969. Johann Arndts Vier Bücher vom wahren Christentum als Beitrag zur protestantischen Irenik des 17. Jahrhunderts: Eine quellenkritische Untersuchung. Marburg: N.G. Elwert.

Wolff, Gottfried. 1989. Solus Christus. Wurzeln der Christusmystik bei Gerhard Tersteegen. Gießen: Brunnen-Verl.

Yamashita, Kazuya. 2000. Kant und der Pietismus: Ein Vergleich der Philosophie Kants mit der Theologie Speners. Berlin: Verl. für Wissenschaft und Forschung.

Zelle, Carsten. 1990. 'Das Erhabene in der Frühaufklärung. Zum Einfluß der englischen Physikotheologie auf Barthold Heinrich Brockes’ >Irdisches Vergnügen in Gott<'. In arcadia. Zeitschrift für vergleichende Literaturwissenschaft 25 (1990). Berlin, New York: de Gruyter. 225-240. 
